\title{
Enablers and Barriers in the Market-Driven Rollout of Smart Metering: Polish Technology Innovation System Analysis
}

\author{
Maksymilian Kochański ${ }^{1,2, * \mathbb{D}}$, Katarzyna Korczak ${ }^{1,2}$ (D) and Tadeusz Skoczkowski ${ }^{1}$ \\ 1 Faculty of Power and Aeronautical Engineering, Warsaw University of Technology, 00-665 Warsaw, Poland; \\ katarzyna.korczak@proakademia.eu (K.K.); tskocz@itc.pw.edu.pl (T.S.) \\ 2 Research and Innovation Centre Pro-Akademia, 95-050 Konstantynów Łódzki, Poland \\ * Correspondence: maksymilian.kochanski@proakademia.eu; Tel.: +48-42-636-12-26
}

check for updates

Citation: Kochański, M.; Korczak, K.; Skoczkowski, T. Enablers and Barriers in the Market-Driven Rollout of Smart Metering: Polish Technology Innovation System Analysis. Energies 2021, 14, 5259. https://doi.org/ $10.3390 /$ en14175259

Academic Editor: Marco Pau

Received: 5 August 2021

Accepted: 23 August 2021

Published: 25 August 2021

Publisher's Note: MDPI stays neutral with regard to jurisdictional claims in published maps and institutional affiliations.

Copyright: (c) 2021 by the authors. Licensee MDPI, Basel, Switzerland. This article is an open access article distributed under the terms and conditions of the Creative Commons Attribution (CC BY) license (https:/ / creativecommons.org/licenses/by/ $4.0 /)$.

\begin{abstract}
This paper is the first country-specific analysis of the market-driven Smart Metering innovation system, covering technologies, actors, and policies. It provides new insights on the key enablers and barriers in the rollout of electricity Smart Meters (SMs) without binding regulatory mandate. The presented research is based on the Technology Innovation System (TIS) analysis for Poland, where an obligation scheme for the rolling out of SMs has been introduced very recently. Still, the number of SMs installed places the country in the top 10 Member States of the European Union. The implementation of SMs is progressing in a complex, multi-actor innovation system, shaped by the leading role of Distribution System Operators (DSOs). The article analyses the key elements of the SM innovation system (technologies and infrastructures, actors and networks, institutions and policies) and characterizes their interaction based on desk research and a critical assessment of regulations, statistics, and literature. The major enablers of the rollout are DSOs expectations of benefits, which have been instigated by the market regulator's benevolence in tariffs approval. On the other hand, the major barriers are delayed and incomplete public policy instruments. Results of the study can inform the development of other market-driven SM deployments around the world.
\end{abstract}

Keywords: Smart Meter; Smart Metering; Technology Innovation System; electricity metering; Poland

\section{Introduction}

In 2009, the European Union (EU) Directive 2009/72/EC was introduced. It required that at least $80 \%$ of consumers shall be equipped with Smart Meters (SMs) by 2020, where the rollout of SMs is evaluated positively by Member States [1]. Each EU Member State was left to decide whether the national SM rollout was economically sound and to choose between a mandated and a market-driven approach. In any case, the proper regulatory intervention has been identified as a necessary measure for both approaches [2].

In 2012, Poland assessed that the long-term benefits of SMs rollout would exceed the costs [3]. The Polish government has concluded that SMs would allow for further liberalization of the electricity market, including the improved access of consumers to electricity consumption data, easier process of supplier switching, and facilitated access to the market for prosumers [4]. The analysis identified several types of benefits for different stakeholders of the energy system: energy savings of final users and simpler supplier change (benefits for customers), reduced time to issue an invoice and new options of demand management (benefits for suppliers), reduction of commercial and technical losses, decrease of meter readings cost, and limiting peak power demand (benefits for Distribution System Operators (DSOs)). Poland was thus included in the group of 17 EU Member States in which cost-benefit analyses yielded a positive result. According to the update of the government study in 2014, by the end of 2018, about $3.5 \mathrm{~m}$ remote reading meters were to be installed across the country. In monetary terms, the benefits of the SM implementation were estimated to exceed 9.48 bn PLN and costs to exceed 9 bn PLN [3]. However, until mid-2021, no obligation scheme for DSOs to install SMs was enforced, no 
state-approved technical requirements were set, and no operator for acquiring and sharing SM data was appointed.

Despite the missing regulatory framework, by the end of 2018, Polish DSOs had already installed nearly $1.5 \mathrm{~m}$ SMs. This placed Poland in the top 10 Member States of the European Union in terms of the number of devices connected to the power grids [5], at the same time being the only country in this group that did not have clear and legally binding regulations for SM deployment. This intriguing observation, suggesting at least a moderate success of the market-driven approach that was followed in Poland, is an important motivation for investigating the enablers and barriers affecting the effectiveness of the Polish case. Both types of factors can be considered as contextual factors of the SM innovation diffusion within the Technology Innovation System (TIS).

Even though market-driven SM rollouts have been progressing within innovation systems of many countries around the world (further discussed in the next section), several questions remain unanswered concerning this approach to SM deployment, and also with regard to Poland. They include, in particular:

- What are the incumbent, emerging, and complementary technologies as well as technological trajectories in market-driven SM rollouts?

- What is the impact of key actors' positions towards SMs on the effectiveness of marketdriven SM deployments?

- What is the influence of regulations, economic and financial instruments, and soft instruments on market-driven SM deployments?

- What are the key enablers and barriers in market-driven rollouts of SMs?

This paper aims to provide new insights on these issues, following the framework of TIS analysis, and referring to the Polish experiences in the SM rollout. Even though it focuses on Poland, its results can inform other market-driven SM deployments. In this context, our key contribution is providing a comprehensive country-specific analysis of the market-driven SM innovation system, covering technologies, actors, and policies. We demonstrate that SM rollout can be successful at the level of a single DSO, even without a binding regulatory framework. We also identify the key enablers and barriers in such a case and provide several policy and practice recommendations.

The rest of this paper is organized as follows. Section 2 describes the literature review concerning prior related work and provides background information on the electricity sector in Poland. Section 3 explains our research approach and methods. Section 4 presents the results, while Section 5 analyses them with respect to the research topic and state-ofthe-art. Section 6 draws conclusions.

\section{Literature Review}

\subsection{Market-Driven SM Rollouts around the World}

Market-driven SM deployments are progressing in many EU Member States, such as Bulgaria, Croatia, Cyprus, the Czech Republic, Hungary, Poland, Portugal, Slovakia, and Latvia, as well as outside Europe, e.g., Brazil and Australia [6,7]. Studying SM deployment based on such voluntary actions of stakeholders of energy systems is of paramount importance for the worldwide implementation of smart grids, smart buildings, and energy management [8-10].

While the diffusion of SM has been discussed in several prior works (Table 1), a comprehensive and single country-specific study of all TIS elements affecting the success of market-driven SM rollouts has not yet been conducted. Still, market-driven SM rollouts (voluntary implementation of SMs without clear legal mandates) deserve attention, especially at a country level, which allows for providing more profound insights than in the case of multi-country comparisons. 
Table 1. Prior related works on TIS of SM rollouts.

\begin{tabular}{|c|c|c|c|c|c|c|c|}
\hline \multirow{2}{*}{\multicolumn{2}{|c|}{ Geographical Focus }} & \multicolumn{2}{|c|}{ Type of SM Rollouts Studied } & \multicolumn{3}{|c|}{ SM TIS Elements Focus } & \multirow{2}{*}{ Reference } \\
\hline & & Mandated & Market-Driven & Technologies & Actors & Policies & \\
\hline \multirow{4}{*}{$\begin{array}{l}\text { Multi-country } \\
\text { studies }\end{array}$} & EU-28 & + & + & + & + & + & [11] \\
\hline & EU-10 & + & + & & & + & [12] \\
\hline & $\begin{array}{c}\text { The Netherlands } \\
\text { UK } \\
\text { Norway } \\
\text { Portugal }\end{array}$ & + & + & + & + & + & [13] \\
\hline & $\begin{array}{l}\text { Denmark } \\
\text { Finland } \\
\text { Germany } \\
\text { The Netherlands } \\
\text { Sweden }\end{array}$ & + & + & & & + & [14] \\
\hline \multirow{7}{*}{$\begin{array}{l}\text { Single country } \\
\text { studies }\end{array}$} & Brazil & & + & & & + & [15] \\
\hline & Finland & + & & + & & & [16] \\
\hline & Hungary & & + & & + & + & [17] \\
\hline & India & + & & & & + & [18] \\
\hline & The Netherlands & + & & + & + & & [19] \\
\hline & The Netherlands & + & & & & + & [20] \\
\hline & Portugal & & + & & + & & [21] \\
\hline
\end{tabular}

The plus sign (+) indicates type of SM rollout studied in the given reference and the SM TIS elements considered therein.

Prior national studies on market-driven SM deployments describe selected aspects of Brazilian, Hungarian, and Portuguese experiences:

- In Brazil, the SM rollout has not been enshrined in any public policy, similar to Poland. Another similarity is the key driver of the SM implementation: the tariff schemes. In particular, the voluntary white tariffs provide customers with a possibility of benefitting from reduced price rates at times of lowest electricity consumption in the power system. Contrary to the Polish case, the pace of the SM rollout is dictated, not by DSOs, but by consumers signing up for this tariff type [15].

- In Hungary, the SM penetration rate in 2018 was among the lowest in the EU-1\%, while at the same time in Poland it was 8.3\% [5]. Similar to Poland, Hungarian policymakers have not set clear procedures, timelines, or obligation schemes for DSOs to implement SMs. A potential explanation for the difference in the effectiveness of rollouts between the two countries is the role of the regulatory authorities. While in Poland they demonstrated an early and clear support for SM implementation (described further in Section 4.3), their Hungarian counterparts failed to move the SM agenda forward [17].

- In Portugal, the SM penetration rate in 2018 was 25\%, after a jump from 10\% in 2017 [5]. The primary difference between the Polish and Portuguese SM cases is the number of DSOs engaged in the rollout; in Portugal there is only one main DSO, whose active role in SM deployment was sufficient to push the rollout even without binding regulations. Its main motivation was to enable demand response programs. They were seen as a promising way of dealing with the increasing share of renewables in the Portuguese power grid [13].

\subsection{Context of the Market-Driven SM Rollout in Poland-The National Electricity Industry}

The SM rollout in Poland is important for all sectors of the Polish electricity industry, including power generation, transmission, and distribution: 
- Generation: Poland has the largest share of fossil generation in the EU. In 2020, the share of fossil fuels in power generation exceeded $80 \%$ [22]. In absolute values terms, between February and July 2020, Poland was Europe's biggest coal-based power generator for the first time ever, as Germany saw a significant coal generation fall [22]. Still, electricity production from renewables is increasing rapidly. A spectacular growth has been observed in Photovoltaics (PVs), especially in prosumer installations. In 2020, PVs supplied the power system with 176\% more energy than in 2019 [23]. In May 2021, the number of prosumers exceeded $0.5 \mathrm{~m}$, i.e., nearly $3 \%$ of electricity end users had their own RES installation [24,25]. Prosumers are the DSOs' priority customers for installing SMs, because introducing an RES installation typically requires replacement of conventional electricity meters with bidirectional ones.

- Transmission: The Polish transmission system is composed of 280 lines with a total length of 15,202 km (220 and $400 \mathrm{kV})$, one $750 \mathrm{kV}$ line with a total length of $114 \mathrm{~km}$ (currently not in use), 109 extra-high voltage stations, and an under-sea $450 \mathrm{kV} \mathrm{DC}$ Poland-Sweden connector [26]. The Polish Transmission System Operator (TSO) is expected to be the biggest beneficiary of the SM rollout [4], mainly due to the peak savings.

- Distribution: The Polish distribution system is dominated by five of the biggest DSOs. PGE, operating in eastern and central Poland, covers the biggest area. The largest distributor in terms of number of customers is Tauron, which supplies energy to over 5.5 million customers on a twice smaller area than PGE. Then there is Energa, which serves 3 million customers in the northern and central part of the country, and Enea, with 2.5 million customers in the west. Innogy in Warsaw provides electricity to $1 \mathrm{~m}$ users. Unlike other players, it is a private company [27]. All DSOs play a central role in SM implementation, as they own the metering systems, and they are in charge of installing them.

\section{Materials and Methods}

Similar to prior research at the EU level [11], our study of the SM rollout in Poland is framed within the approach of TIS analysis. Exploring the processes of the SM diffusion entails the identification and characterization of not only technological but also economic and social domains in which the innovation processes run, at the same time investigating the interactions between the system actors and institutions [28]. To this end, we address the following three specific elements of SM TIS in Poland:

1. Technologies and infrastructures, with regard to which we analyze the past development of SM technologies and infrastructures in which SMs are rolled out;

2. Actors and networks in the SM rollout, with regard to which we map key stakeholders, i.e., public and private institutions as well as their collaboration platforms;

3. Policy instruments affecting SM rollouts, with regard to which we follow the classification of the policy instruments of Peñasco, Verdolini, and Larkin [29]. We exclude from the analysis five policy instruments from the classification that are not applicable to SM TIS (i.e., emissions standards, funds to sub-national governments, auctions, green certificates, and comparison labels).

Based on the analysis of the above TIS elements, we investigate how their interactions affect the SM implementation by tracing the development and diffusion of SM innovation. To this end, we critically analyze the scientific and grey literature (e.g., market research reports) and regulations published between 1990 and July 2021. To narrow down the scope of the study on the one hand, and to ensure a sufficient level of detail of the research findings on the other, the scope of research concerning SM in this paper is limited to SM systems in Poland, yet its conclusions are relevant for SM implementations at other locations as well. Furthermore, only electricity SM are studied, while meters used for other energy carriers (e.g., gas SMs) are excluded. 


\section{Results}

\subsection{Technologies and Infrastructures}

\subsubsection{Incumbent and Emerging Technologies}

In 2019, over 12 m electricity meters (including SMs) were produced in Poland, hitting a record high (Figure 1, based on [30-32]). Between 2009 and 2019, the annual production of electricity meters increased by over eleven times. In view of the number of electricity end-users (17.4 m) [25], this suggests a strong export capacity of the Polish market.

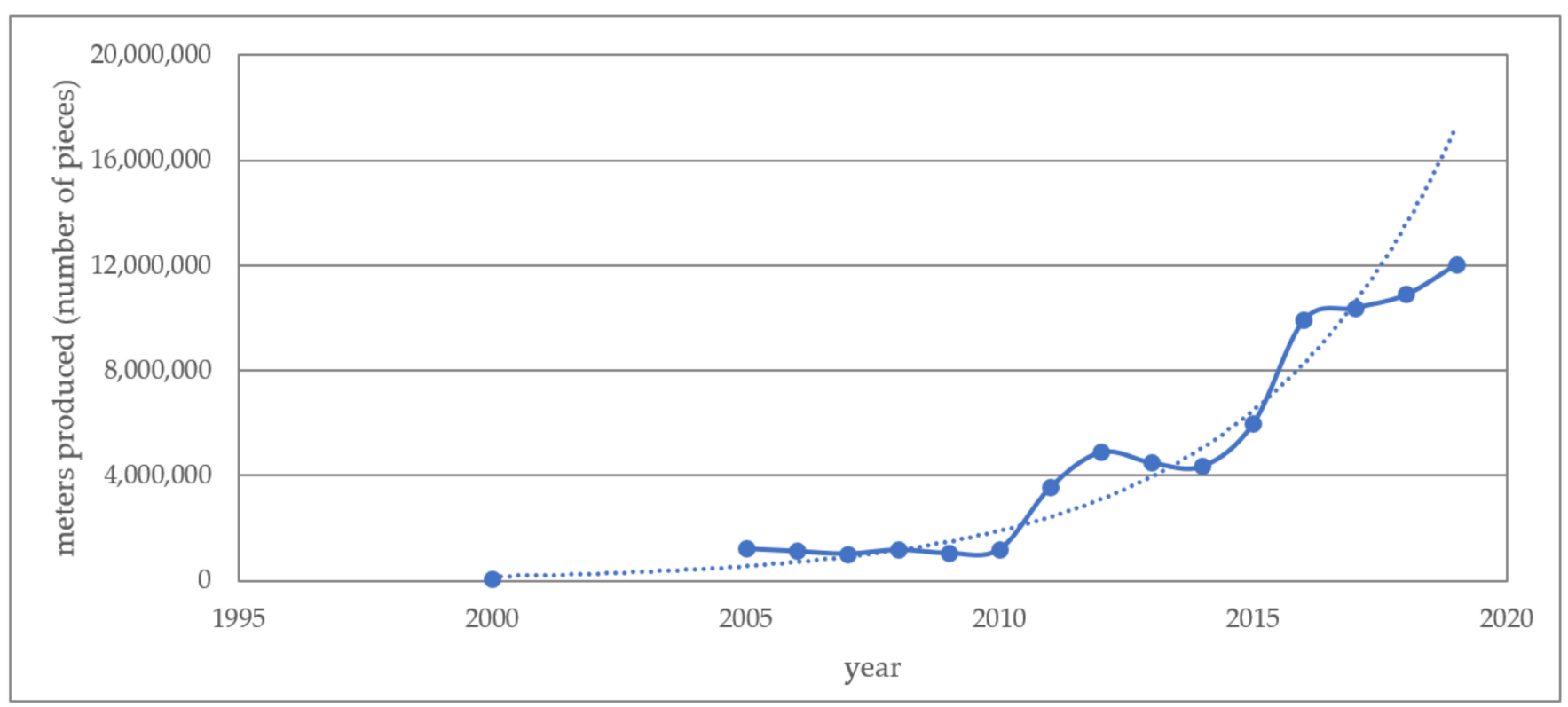

Figure 1. Production of electricity meters (all types, including SMs) in Poland between 2000 and 2019 (pcs).

The energy induction meters are the most prevalent and oldest commonly used meter type in Poland [33]. However, Polish DSOs started installing more advanced measuring devices (SMs) in 2013 [34]. By the end of 2020, 9.2\% of Polish households had been equipped with SMs, including both consumers and prosumers of energy $(1.6 \mathrm{~m}$ and $0.4 \mathrm{~m}$ SMs, respectively) [35,36].

The legal validity period for active energy induction meters with a capacity not higher than $30 \mathrm{~kW}$ in Poland is 15 years, while for other types of meters, the period is 8 years [37]. After this time, each meter must be checked to ensure it has not become obsolete or replaced with a new meter (e.g., a smart one). In this context, as well as in view of the recent changes in the regulatory framework (explained in the later sections of this paper), it is expected that standard, non-electronic induction meters will become obsolete in Poland by 2030. Other technologies likely to become obsolete are unidirectional energy meters (which do not allow for net metering for prosumers) and meters not resistant to the external magnetic field (due to the threat of meter tampering).

An example of an SM produced in Poland is the SMARTEMU-3 by Apator, which uses PLC or $3 \mathrm{G}$ communications, depending on the product version. Another type of $\mathrm{SM}$ solution is the OneMeter beacon, produced by a start-up of the same name, which enables SM functionalities in existing standard electricity meters. In its standard operation mode, OneMeter beacons read data from meters every $15 \mathrm{~min}$ and store it in an internal memory. A stored energy profile can be viewed in a dedicated web application. The beacon uses communications working in the $2.4 \mathrm{GHz}$ range and an AES-128 encryption protocol. Electronic meters, which, after equipping with additional telecommunications devices, such as OneMeter beacons, would allow for a remote acquisition of measurement data, are used by three of the five largest DSOs: Tauron, PGE, and Innogy. However, the DSOs are 
sceptical about upgrading their existing meters with additional external devices enabling remote readings [38].

\subsubsection{Complementary Technologies and Services}

The level of disturbances in the low voltage network is constantly growing due to the increasing use of switched power supplies, frequency converters, nonlinear inductive devices, thyristor controllers, and LED lighting. In this context, a complementary technology emerges, i.e., anti-interference filters, e.g., by Maschek Polska, which reduce interferences to a level that enables reliable communication between energy meters and data concentrators. In addition to complementary products, complementary services are also emerging on the market. In 2017, Tauron Dystrybucja was the first DSO in Poland to provide its clients with the Home Area Network (HAN): a Tauron AMIplus service that allows remote activation of the wireless communication interface with an SM using Wireless M-Bus. Data on energy consumption is passed to the domestic receiving device. The HAN network allows households not only to connect several different 'smart home' devices but also enables data exchange with SM and control of BAS devices and communication with other IoT devices.

\subsubsection{Technological Trajectories}

Five main technological areas of SM development in Poland can be distinguished: data collection (measurement), data storage, data communication (technology/protocol), data security, and data display (Table 2). These are the areas of technological advancements in SM that consistently develop over time through the accumulation of knowledge. The presented specification of technological trajectories is a generalization based, on the one hand, on the technical standard published in 2018 by the PTPiREE-an industrial association uniting inter alia Polish DSOs [39]) and, on the other hand, on two products offered on the Polish market on a large scale, namely: (1) SMARTEMU-3 - an SM produced by Apator, a Polish company, which are sold inter alia to Tauron and Energa, the DSO that is the SM leader in Poland; (2) AD13A.1-3-1—an SM produced by ADD Group, a company based in Moldova, which are used also by Energa.

While assessing the maturity of the discussed five technological areas, the first two (measurement and data storage) could be regarded as well-established, with limited innovation potential. Technological accelerations (experimentation, research activities, new standards) are most visible in the last three fields. First, in the data communications area, there is an observable process of technology pathway testing (PLC vs. GSM/GPRS/EDGE/LTE). Second, in the data security area, the requirements concerning Advanced Encryption Standard (AES) are becoming stricter-from 128 bit to higher levels. Third, in the data display and identification area, the Object Identification System (OBIS) codes are subject to frequent amendments (For instance: (1) PN-EN 62056-61:2003-published on 15 June 2003, revoked on 26 June 2007; (2) PN-EN 62056-61:2007-published on 26 June 2007, revoked on 22 April 2009; (3) PN-EN 62056-61:2009_published on 22 April 2009, revoked on 05 February 2014; (4) PN-EN 62056-6-1:2014-02-published on 05 February 2014, revoked on 07 February 2017; (5) PN-EN 62056-6-1:2017-02 - published on 07 February 2017, revoked on 07 February 2018; (6) PN-EN 62056-6-1:2018-02_published on 07 February 2018.) [40].

Despite the identified areas for technological developments and innovation, low patenting activities in SMs are observed. Between 2010 and 2020, only 18 successful patents in electricity metering were granted by the Polish Patent Office (Figure 2, key words used: 'electricity meter', 70 relevant results found in the Polish Patent Office, status as of July 2021). 
Table 2. Examples of technical specifications of SMs installed in Poland—emerging technological trajectories and the level of technology and market development.

\begin{tabular}{|c|c|c|c|c|c|c|}
\hline No. & Technological Area & $\begin{array}{c}\text { SM 1: } \\
\text { SMARTEMU-3 } \\
\text { by Apator } \\
\text { (Polish Producer, } \\
\text { WSE-Listed Company) } \\
\text { (2014) }\end{array}$ & $\begin{array}{c}\text { SM 2: AD13A.1-3-1 by ADD } \\
\text { Group (Moldovan Producer, } \\
\text { Sold 420,000 m to Polish DSO } \\
\text { Energa) (2017) }\end{array}$ & $\begin{array}{l}\text { Requirements of the "Draft of } \\
\text { Technical Requirements for Static } \\
\text { Direct Electricity Meters" (Technical } \\
\text { Standard Published by the } \\
\text { PTPiREE-Chamber Uniting Inter } \\
\text { Alia Polish DSOs) (2018) }\end{array}$ & $\begin{array}{l}\text { Technological } \\
\text { Trajectories }\end{array}$ & $\begin{array}{l}\text { Assessed Level of } \\
\text { Technology and } \\
\text { Market Development }\end{array}$ \\
\hline 1 & $\begin{array}{l}\text { Data collection } \\
\text { (measurement) }\end{array}$ & Bidirectional & Bidirectional & Bidirectional & Bidirectional & stabilisation \\
\hline 2 & Data storage & $\begin{array}{l}\text { storage of the monthly } \\
\text { load profiles in the } \\
\text { memory }\end{array}$ & $\begin{array}{l}15 \text { min interval profile: } \\
6 \text { parameters for about } 63 \text { days }\end{array}$ & $\begin{array}{c}\text { Storage of the load profile in the } \\
\text { memory for at least } 63 \text { days at } 15 \mathrm{~min} \\
\text { sampling period for six measurement } \\
\text { quantities }\end{array}$ & $\begin{array}{l}\text { Storage of the load } \\
\text { profile in the memory for } \\
\text { at least } 63 \text { days at } 15 \text { min } \\
\text { sampling period for six } \\
\text { measurement quantities }\end{array}$ & stabilisation \\
\hline 3 & $\begin{array}{l}\text { Data communication } \\
\text { (technology/protocol) }\end{array}$ & $\begin{array}{l}\text { Basic communication } \\
\text { module: PLC Prime, } \\
\text { PLC OSGP GSM/3G, } \\
\text { USB, MBus, optionally: } \\
\text { RS-232/RS-485 }\end{array}$ & $\begin{array}{c}\text { PLC: } \\
\text { - } \quad \text { Built-in OFDM PLC modem } \\
\text { - } \quad \text { Two RS-485 outputs on a } \\
\text { common bus, providing WAN } \\
\text { communication (via 3GPP } \\
\text { module) } \\
\text { Data concentrator communication } \\
\text { channels: PL LV, 2G (GSM/GPRS) } \\
\text { (800 MHz, 850 MHz, 900 MHz, } \\
1800 \mathrm{MHz}, 1900 \mathrm{MHz}), 3 \mathrm{G} \\
\text { (UMTS) (2100 MHz, 1900 MHz, } \\
800 \mathrm{MHz}, 900 \mathrm{MHz}), 4 \mathrm{G}(\mathrm{LTE}) \\
(2100 \mathrm{MHz}, 1800 \mathrm{MHz})\end{array}$ & $\begin{array}{c}\text { 1. LTE: B3 (1800 MHz), B7 } \\
\text { (2600 MHz), B8 (900 MHz), B20 } \\
\text { (800 MHz), } \\
\text { 2. GSM/GPRS/EDGE: } \\
900 / 1800 \mathrm{MHz}\end{array}$ & $\begin{array}{l}\text { 1. LTE: } \\
\text { (a) } 1800 \mathrm{MHz} \\
\text { (b) } 2600 \mathrm{MHz} \\
\text { (c) } 900 \mathrm{MHz} \\
\text { (d) } 800 \mathrm{MHz} \\
\text { (e) } 450 \mathrm{MHz} \\
\text { 2. GSM/GPRS/EDGE: } \\
\text { (a) } 900 \mathrm{MHz} \\
\text { (b) } 1800 \mathrm{MHz}\end{array}$ & acceleration \\
\hline 4 & Data security & $\begin{array}{l}\text { DLMS/COSEM, } \\
\text { AES128 encryption }\end{array}$ & $\begin{array}{l}\text { DLMS/COSEM, } \\
\text { AES-GCM-128 }\end{array}$ & $\begin{array}{l}\text { DLMS/COSEM, AES at least } 128 \text { bit } \\
\text { (HLS), TLS v.1.3 mechanisms } \\
\text { protecting against DoS/DDoS attacks. }\end{array}$ & $\begin{array}{l}\text { DLMS/COSEM } \\
\text { AES } 128 \text { bit }\end{array}$ & acceleration \\
\hline 5 & $\begin{array}{l}\text { Data display and } \\
\text { identification }\end{array}$ & $\begin{array}{l}\text { LCD (messages based on } \\
\text { OBIS codes; PN-EN } \\
62056-61 \text { ) }\end{array}$ & $\begin{array}{c}\text { LCD, } 8 \text { digits, configurable } \\
\text { decimal place (up to } 3 \text { digits); } \\
\text { special symbols, data } \\
\text { identification according to IEC } \\
62056-61 \text { (OBIS) }\end{array}$ & $\begin{array}{l}\text { LCD (messages based on OBIS codes; } \\
\text { PN-EN 62056-61) }\end{array}$ & $\begin{array}{l}\text { LCD, OBIS codes; } \\
\text { PN-EN 62056-61 }\end{array}$ & acceleration \\
\hline
\end{tabular}




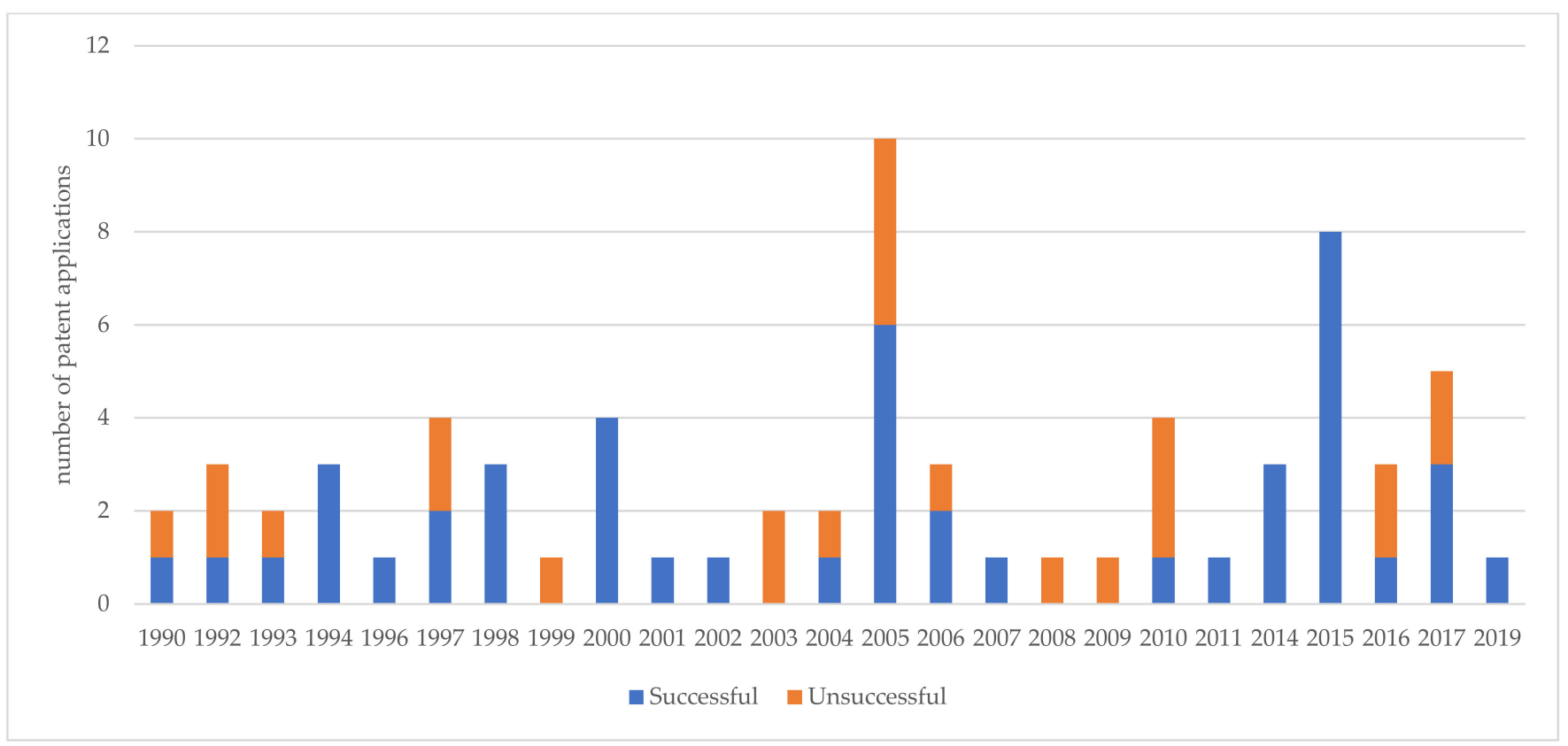

Figure 2. Patent applications in the field of electricity metering submitted to Polish Patent Office (1990-2020).

\subsection{Actors and Networks}

\subsubsection{Demand}

The first group of demand-side actors of SM systems in Poland are their main endusers, i.e., consumers. Polish consumers have a low level of awareness regarding SM as a technology and their benefits in terms of energy efficiency and savings. Forty percent of Poles have never encountered the term ' $\mathrm{SM}$ ' and usually cannot define its meaning [45]. Only every fifth person $(21.2 \%)$ declares that they know exactly what the term means. Television and friends were among the most essential sources of information on SM (respectively, 26.6 and 26.4\%) [45]. However, people who came across this concept acquired their knowledge most often from the Internet (62.8\%) [45]. The first significant wave of interest in SM was observed in March 2009 (Figure 3, based on Google Trends; numbers represent search interest relative to the highest point on the chart for the given region and time. A value of 100 is the peak popularity for the term. A value of 50 means that the term is half as popular. A score of 0 means there was not enough data for this term). The biggest interest on this topic online was registered in April 2013, which was potentially caused by the publication of the cost-benefit analysis of the SM rollout by the Polish Ministry of Economy [4].

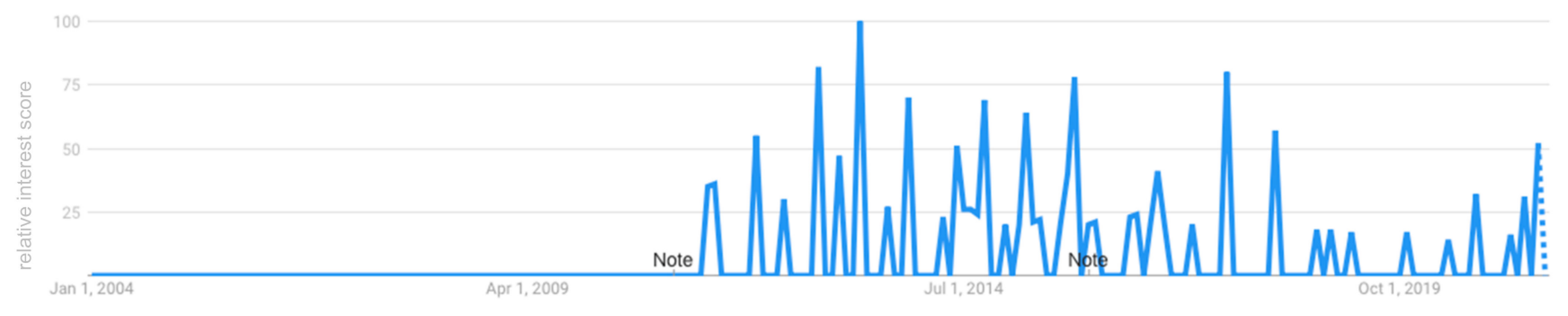

Figure 3. Interest over time results for ‘Inteligentne liczniki' (in English: 'Smart Meters') over 2004—July 2021.

Consumers do not play an essential role in the current stage of the SM rollout in Poland. They have no power to push DSOs to install SMs, or to install them on their own. 
However, they could inhibit the rollout in case of their active disagreement for SM. This phenomenon, for instance, can be observed in France [11]. Still, no such anti-SM movement has been observed in Poland so far.

The second group of demand-side actors of SM systems in Poland are their owners, i.e., DSOs. There are five major DSOs in Poland (Figure 4, based on [38,46-50]). They play a crucial role in the Polish SM innovation system, as they are responsible for SM deployment, as well as several critical functions in power grids [51]. According to Energy Law, the DSOs must submit their development plans to the Energy Regulatory Office (URE) for approval. The plans must include inter alia information about projects in acquisition, transmission, and processing of measurement data from remote reading meters. However, there is no obligation to include any SM rollout projects in the plan.

Enea

Number of customers: 2600 thousand

Number of SM installed: 35 thousand (2018)

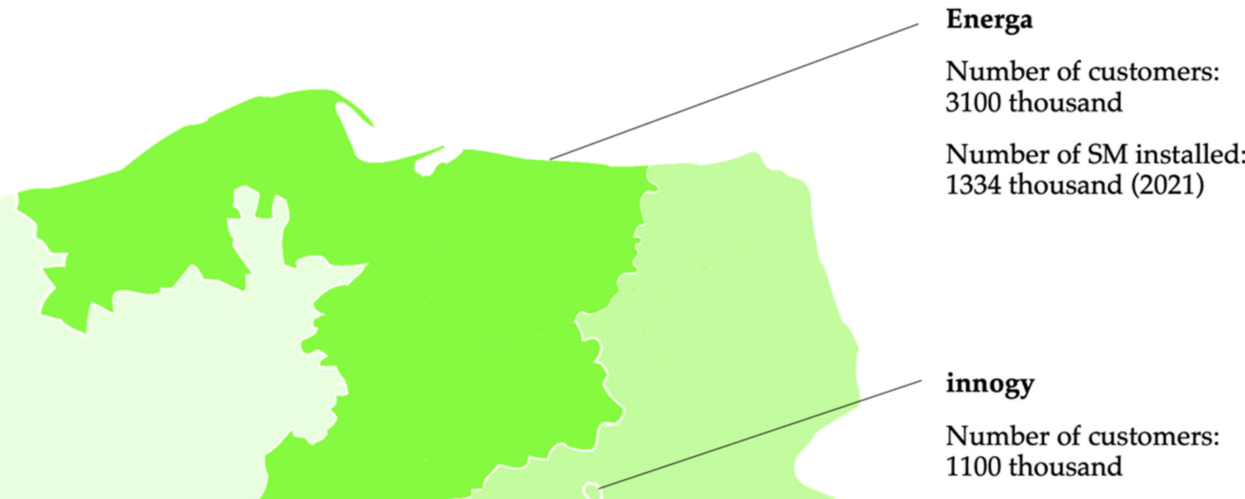

Number of SM installed: 106 thousand (2019)

\section{PGE}

Number of customers: 5500 thousand

Number of SM installed: 350 thousand (2020)

\section{Share of customers}

equipped with SM:

$0-5 \%$

$5-10 \%$

$>10 \%$

Figure 4. SM penetration in the power grids of the five main DSOs in Poland.

The national leader in terms of the share of SM in the total number of owned meters is Energa-Operator (SMs installed at nearly 50\% of customers), followed by Innogy Stoen Operator, Dystrybucja and PGE Dystrybucja. Energa-Operator started the implementation of the Tauron pilot SM projects as the first DSO in Poland in 2013 (pilot in Kalisz City) [34]. Already in the following year, in the districts in which Energa-Operator installed SMs, technical and commercial losses decreased by approximataly $10 \%$, which resulted from fraud prevention and eliminating technical losses. It resulted in significant savings, which were partly invested in further modernization of the power grid [33,34].

While the success of Energa was preceded by a long preparatory phase that started in 2011, the other four operators have not been so enthusiastic about SMs in the early 2010's. For instance, Enea Operator, already in 2011, explained that investments in SMs are not fully profitable for DSOs [52]. Still, all four DSOs started their SM rollouts after the positive experiences of Energa. As of July 2021, customers of PGE, Tauron, and Energa that are equipped with SMs have the option of tracking their energy consumption on the website 
or in the mobile application. Enea announced the launch of such functionality in 2019, and Innogy Stoen Operator declared the same with no specific date set.

\subsubsection{Supply}

The total value of sold electricity meters in Poland in 2019 was over 1.2 bn PLN [32], though there is no data on the share of SMs in this number. The major suppliers of SMs are Grupa Apator (Torun, Poland), T-MATIC System SA (Warsaw, Poland), Systemy Pomiarowe Elgama Ltd. (Świdnica, Poland), and Landis+Gyr (Zug, Switzerland). The leading manufacturers of the SMs installed in Poland are from Poland, Switzerland, and Moldova.

Grupa Apator is a capital group with over a 50\% market share in the supply of SMs in Poland [36]. It currently consists of fifteen companies-nine domestic and six foreign. The parent entity of the group is Apator Joint Stock Company-a Polish company of the electromechanical industry with headquarters in Torun, listed on the Warsaw Stock Exchange. Apator offers systems for measuring and providing electricity, compliant with IEC and PRIME standards, available with various communication technologies (PLC: PRIME and OSGP; G3 and LTE: Cat.1, Cat.4, Cat. M1, LTE 450) [53]. Every year, it produces more than $1 \mathrm{~m}$ electricity meters [54]. The company's SMs have been installed both in Poland (e.g., in Wroclaw for Tauron Dystrybucja and in Warsaw for Innogy), as well as abroad, e.g., in Lithuania [55]. The firm considers that the key challenges for the $\mathrm{SM}$ rollout are the human resources required for meter installation and cybersecurity requirements [53]. Apator expects that, by 2028, roughly13-14 $\mathrm{m}$ new meters with a remote reading functionality will be placed on the domestic market, with 1.6 to $2.5 \mathrm{~m}$ units to be installed per year [36]. In view of the further expected price erosion, the company plans to profit from production capacity growth and faster sales.

T-MATIC System SA, based in Warsaw, is an official distributor of products of the Moldovan producer, ADD Group, as well as a member of the international association promoting an open standard of communication in intelligent energy networks, PRIME Alliance. Four-hundred thousand Moldovan SMs have been installed in Poland by Energa-Operator.

The company Systemy Pomiarowe Elgama Ltd., based in Świdnica (Lower Silesia), has been operating on the market of SM systems since 2004. In 2014, Energa-Operator signed a contract for the installation of 450,000 SMs compliant with the requirements of URE with the consortium of Elgama and its Lithuanian partners (UAB Sigma Telas Energy and UAB Elgama-Elektronika) [54].

Landis+Gyr is a Swiss corporation operating in 30 countries on 5 continents. Owned by Toshiba, it is currently one of the world's largest producers of SMs. In 2014, the company signed a contract with the RWE Group (currently, Innogy) for providing 100,000 devices and software for the installation of SMs in Warsaw.

Apart from the above-listed big suppliers, there are also niche actors: start-ups and spinoffs (e.g., OneMeter), who work on innovations that deviate from existing regimes (e.g., the OneMeter beacon).

\subsubsection{Research and Education}

The number of research and education institutions engaged in SM research in Poland is not very high. According to a Polish National Science Centre database query, the Centre has funded only five projects, whose titles refer to Smart Grids (SGs) or SMs (query date: July 2021). They were implemented by: (1) AGH University of Science and Technology in Cracow; (2) Wroclaw University of Technology, (3) Gdańsk University of Technology; (4) University of Zielona Góra; and (5) Warsaw University of Life Sciences. An interesting initiative implemented by the research and education actors in the field of SMs were the 'AMI Picnics', events popularizing SMs, organized by AGH University of Science and Technology in Cracow in collaboration with Wrocław University of Technology and Tauron Dystrybucja [56]. During these events, held in 2014 and 2015, comparative tests of SMs from various producers were performed. 


\subsubsection{Supporting Institutions-Government Bodies}

The Ministry for Energy (ME) sets and implements the national energy policy in accordance with the EU legislation. In particular, the ME is responsible for controlling energy markets, providing energy security to the country, and promoting and implementing energy efficiency schemes. Furthermore, the ME is in charge of energy infrastructure, including the electricity metering system regulations and supervising the Energy Regulatory Office [57].

The Energy Regulatory Office (Urząd Regulacji Energetyki, URE) is a central body of the state administration, established in 1997 based on the Energy Law. URE approves tariffs prepared by DSOs as well as their draft development plans, including planned investments in SM rollouts [58].

The Personal Data Protection Office (Urząd Ochrony Danych Osobowych, UODO) is another central body of state administration, established in 2018 on the basis of the Protection of Personal Data Act. The main duty of UODO is to protect people in connection with the processing of personal data, according to the requirements of the General Data Protection Regulation (EU 2016/679). As SM data are treated in Poland as personal data, UODO plays the role of a guard, upholding unjustified processing of data from SMs.

The Central Office of Measures (Główny Urząd Miar, GUM) is a central body of the state administration, established on the basis of the Law on Measures in 2004. GUM's main competence is to ensure the compliance and accuracy of the national measurement standards and their traceability to the international measurement standards. Electricity meters installed by DSOs must be approved by GUM.

The Supreme Audit Office (Najwyższa Izba Kontroli, NIK) is the top independent state audit body, which is subordinate to the Sejm (the lower chamber of the Polish Parliament). NIK's objective is to ensure that public finance is spent reasonably and according to the law. NIK is in charge of controlling public authorities as well as four out of the five largest Polish DSOs, which are partially owned by the state (all except Innogy Stoen Operator).

\subsubsection{Supporting Institutions-Industrial and Financial Institutions}

The Polish Power Transmission and Distribution Association (Polskie Towarzystwo Przesyłu i Rozdziału Energii Elektrycznej, PTPiREE) is an industrial organization established in 1990 by several DSOs (Enea Operator, Energa-Operator, PGE Dystrybucja, Tauron Dystrybucja, Innogy Stoen Operator, and PKP Energetyka) and the Transmission System Operator. Its aim is to support the transformation of the Polish power industry by consulting services, training, and publications. PTPiREE actively works on new technologies and standards. In 2018, in the absence of public regulations, PTPiREE developed and published a technical standard for SM: "Draft of technical requirements for static direct electricity meters" [39].

The Polish Chamber of Informatics and Telecommunication (Polska Izba Informatyki i Telekomunikacji, PIIT) is an organization gathering Polish companies working in the field of digital transformation. PIIT's aim is to provide supporting conditions for the development of the ICT industry, to ease collaboration between the ICT industry and public administration, and to support the development of regulations that would support digital innovation. In 2018, PIIT joined the technical dialogue concerning SMs in Poland, pointing out that the frequency bands proposed in the SM specification by PTPiREE should be expanded by $450 \mathrm{MHz}$, as omitting this band would mean the inability to ensure proper electricity readings in this frequency range or the need to replace communication modules in all meters in the future, which would be associated with high costs [59].

Polskie Sieci Elektroenergetyczne S.A. (PSE) is the National Transmission System Operator in Poland, fully owned by the State Treasury. According to the energy law amendment of 2021, it was entrusted with the tasks of Energy Market Information Operator [60]. The company has been mandated to establish and manage the Central Energy Market Information System (CSIRE). Therefore, it will collect and process all electricity metering data necessary, inter alia, to change the electricity supplier or make settlements for its 
sale and delivery. Thanks to the unification of information standards processed in CSIRE, the processes taking place on the retail electricity market in Poland are expected to be significantly streamlined and accelerated.

The Bank for Environmental Protection (Bank Ochrony Środowiska, BOŚ) is a Polish bank providing preferential loans for environmental investments, such as renewables, energy efficiency, waste and water management, urban areas revitalization, and others [61]. Since its establishment in 1991, BOŚ contributed 18.6 bn PLN (EUR 4.5 bn) to finance environmental projects [62].

The National Fund for Environmental Protection and Water Management (Narodowy Fundusz Ochrony Środowiska i Gospodarki Wodnej, NFOŚiGW) is a public body supporting the ecological activities of Polish institutions, both public and private ones. Its budget comes from charges and fines for using the environment, maintenance and concession charges, energy sector charges, charges resulting from the Act on recycling of vehicles withdrawn from use, and sales of GHG emission units. NFOŚiGW is also funded from foreign sources. NFOŚiGW provides beneficiaries with grants and soft loans for activities related to water and sewage treatment, thermal upgrade of buildings, and renewable energy sources. In 2014, NFOŚiGW launched a program "Energy efficiency improvement, Part 1, SGs" with a budget of $172 \mathrm{~m}$ PLN (EUR $43 \mathrm{~m}$ ). The program was addressed to DSOs and electricity suppliers and aimed at launching pilots of SGs, which could include SM. The project was finished in 2017 [63]. As of 2021, no other program for SMs is available at NFOŚiGW.

\subsection{Policy Instruments}

This section analyses and assesses regulations, economic and financial instruments, and soft instruments addressing SMs in Poland (Table 3).

\subsubsection{Regulation-Building Codes}

The Polish building code requires equipping buildings with electricity meters [64]. However, no requirements concerning SMs are provided. Therefore, building codes can be regarded as regulation instruments that are not effectively used in Poland for SM TIS development.

\subsubsection{Regulations-Product Standards}

As of July 2021, no regulation on technical requirements for SM has been formally adopted by the Polish government. The currently binding related standard is the general regulation on the measuring instruments subject to legal metrological control [24], which does not include any requirements concerning remote reading, data storage, or communication protocols. In the absence of legal regulations of SM standards, Polish producers of SMs in principle also refer to the technical requirements binding standard electricity meters: Measuring Instruments Directive [65] and technical standards, such as PN-EN 50470-1, PN-EN 50470-3, PN-EN 62053-23 418. On the other hand, DSOs refer to their own internally-developed technical requirements (e.g., [66]) or the standards developed by PTPiREE [39].

The main governmental document explicitly dedicated to SM was published to provide guidelines for the public procurement of SM systems by URE in 2015 [67]. The technical documentation comprises the requirements for meters and concentrators and the organization of communication at each stage: from the data acquisition system at the level of the network operator to the home gateway in the client's home network infrastructure. The specification was the result of the work of URE and industrial organizations, including PTPiREE and DSOs. In the metrological and construction section of the documentation, the parties involved in the process reached an agreement. Hence, this section of the specification has a reference value. With regard to the communication section of the document, it was not possible to establish a unified position, and a number of decisions were left to individual investors. 
Table 3. Assessment of policy instruments addressing SM TIS in Poland.

\begin{tabular}{|c|c|c|c|c|c|}
\hline & \multirow[b]{2}{*}{ Policy Instrument } & & \multicolumn{3}{|c|}{ Assessment of the Instrument Use } \\
\hline & & & $\begin{array}{l}\text { Not Used/Underdeveloped/ } \\
\text { Implementation Delayed }\end{array}$ & $\begin{array}{l}\text { Used in a Limited Extent/ } \\
\text { Not Effectively, Plans Exist }\end{array}$ & Actively Used \\
\hline \multirow{6}{*}{ Regulations } & \multirow{4}{*}{$\begin{array}{c}\text { Codes/ } \\
\text { standards/ } \\
\text { mandates }\end{array}$} & $\begin{array}{l}\text { Building codes } \\
\text { and standards }\end{array}$ & + & & \\
\hline & & Product standards & + & & \\
\hline & & Sectoral standards & + & & \\
\hline & & Auditing & & & + \\
\hline & $\begin{array}{l}\text { Obligation schemes/ } \\
\text { quotas }\end{array}$ & Obligation schemes & + & & \\
\hline & Other regulation & Net metering & & + & \\
\hline \multirow{7}{*}{$\begin{array}{l}\text { Economic and } \\
\text { financial } \\
\text { instruments }\end{array}$} & \multirow{2}{*}{ Direct investment } & Government procurement & & + & \\
\hline & & RD\&D funding & & + & \\
\hline & \multirow{4}{*}{$\begin{array}{l}\text { Fiscal/financial } \\
\text { incentives }\end{array}$} & Tariffs & & & + \\
\hline & & Grants and subsidies & & + & \\
\hline & & Loans/soft loans & & + & \\
\hline & & Taxes-tax relief/exemption & + & & \\
\hline & $\begin{array}{c}\text { Market-based } \\
\text { instruments }\end{array}$ & White certificates & + & & \\
\hline \multirow{7}{*}{$\begin{array}{c}\text { Soft } \\
\text { instruments }\end{array}$} & Performance labels & Endorsement label & + & & \\
\hline & \multirow{3}{*}{$\begin{array}{l}\text { Information } \\
\text { campaigns }\end{array}$} & By energy agencies & & + & \\
\hline & & By energy suppliers & & + & \\
\hline & & By other institutions & & + & \\
\hline & \multirow{3}{*}{$\begin{array}{l}\text { Voluntary } \\
\text { approaches }\end{array}$} & $\begin{array}{l}\text { Negotiated Agreements } \\
\text { (Public-private sector) }\end{array}$ & + & & \\
\hline & & Public Voluntary Schemes & + & & \\
\hline & & $\begin{array}{l}\text { Unilateral Commitments } \\
\text { (Private sector) }\end{array}$ & + & & \\
\hline
\end{tabular}

The plus sign (+) indicates the assessment of each policy instrument using the scale provided. 
The Polish Chamber of Commerce for Electronics and Telecommunications proposed technical and performance requirements for 1- and 3-phase meters, designed for operation in Polish AMI systems [68]. The document was based on international standards and specifications developed in previous years by the PTPiREE and URE and experience gained from the first SM pilots. The document covers all aspects related to the construction and functions of a modern energy meter, in particular the requirements for measurement and communication functions as well as the availability of data for the end-user to optimize energy consumption and production using renewable sources. The specification is based on open standards, and the emphasis is on the measurement of energy quality, the availability of measurement data in real time, interoperability, and information security. The document was sent to the relevant ministries with a request to adopt the relevant technical regulation. In 2018, the Chamber announced that consultations concerning the "Draft of technical requirements for static direct electricity meters" had been completed [69]. The requirements were targeted in particular at industrial consumers. The document may be used by all interested parties and, in particular, for procurement procedures carried out by DSOs associated with the Chamber. Despite several industry-led standardization initiatives, in view of the limited government's activity in the SM standardization area, product standards can be regarded as regulation instruments that are not effectively used in Poland to support the SM TIS development.

\subsubsection{Regulations-Sectoral Standards}

The standardization for cross-sectoral digitization of the Polish energy transition is not coordinated by any designated governmental body. There are fragmented regulations, e.g., according to art. 117 of the Law on Personal Data Protection [70], the DSOs, who install remote reading meters at the sites of end-users connected to their network, are obliged to protect measurement data regarding these end-users on the terms set out in the provisions of the Law on Personal Data Protection. Even though there were several governmental declarations on the planned sectoral standards concerning SGs, as of July 2021, there were no binding governmental regulations. Overall, sectoral standards can be regarded as regulation instruments supporting SM TIS development that are significantly delayed in Poland.

\subsubsection{Regulations-Auditing}

In 2018, NIK negatively assessed the activity of the ME in the area of the SM rollout [3]. It stressed that the prolonging process of the SM deployment and the missing obligation scheme negatively affected Polish consumers' capacities for active energy management and achieving energy savings. NIK noted that the directive 2009/72/EC had not been fully implemented in the Polish legislation, as a strategy of the SM rollout had been delayed, and no division of tasks and responsibilities among energy market participants had been set. The ME did not specify uniform technical and functional requirements for DSOs for SM and good practices that would ensure the same standard of network and SM operation at individual DSOs throughout the country. The delay resulted in lost benefits. It was estimated that Polish households lost $78 \mathrm{~m}$ PLN (EUR $18.5 \mathrm{~m}$ ) in 2017 alone.

Overall, auditing can be regarded as an SM TIS development regulation instrument that is effectively used in Poland. Still, no evidence has been found on the effective follow-up of the audit findings.

\subsubsection{Regulations-Obligation Schemes}

Following EU regulations [1] and the positive results of the cost-benefit assessment [3], Poland was required to prepare a timetable with a target for the implementation of Smart Metering systems in at least $80 \%$ of households by 2020 . The first draft of the energy law amendment, setting an obligation for DSOs to install SMs, was presented in 2011 [71]. However, according to the ME, the work had to be stopped until the new European regulation on the internal electricity market is adopted [3]. Due to the prolonging policy 
making process, it took over 10 years to pass the bill's final version. The regulation adopted in 2021 requires DSOs to install SMs in at least 80\% of end-users, including at least $80 \%$ of households, by 2028, with intermediate targets set for 2023, 2025, and 2027 (15\%, 35\%, $65 \%$, respectively) [60]. Overall, the obligation scheme can be regarded as a regulation instrument that has been significantly delayed.

\subsubsection{Regulations-Carbon Emissions Reduction Target}

No Polish regulation setting Carbon Emissions Reduction Targets for SM has been identified. Therefore, Carbon Emissions Reduction Targets can be regarded as regulation instruments that are not used to support SM TIS development in Poland.

\subsubsection{Regulations-Net Metering}

The crucial regulation on net metering in Poland is the Law on Renewable Energy Sources [72]. Producers of energy from renewables may conclude an agreement for the sale of electricity, based on which the settlement of the difference between the amount of electricity collected from the grid and the amount of electricity introduced into the grid is carried out in the given half-year. Settlements are made on the basis of actual indications of metering and billing devices. Therefore, installing SMs at the facilities of prosumers has been a priority for DSOs, as evidenced by the fact that $20 \%$ of SMs are installed for this type of consumers [36]. However, the power grid regulations in net metering do not require the use of SM systems. Therefore, net metering can be regarded as a regulation instrument that is not used effectively in Poland for SM TIS development.

\subsubsection{Economic and Financial Instruments-Government Procurement}

Forty-seven public procurements related to SM were awarded in Poland between 2012 and 2019. Most procurements (42 awards) were run by utilities [73]. Furthermore, three out of four notices on "Innovation Partnerships" for the supply of energy meters in the whole EU were announced in Poland. Enea Operator, one of the main Polish DSOs, published three notices for the design, production, and delivery of up to 30,000 electricity balancing meters to measure the $\mathrm{MV} / \mathrm{LV}$ stations meeting the requirements specified in the model technical specification published by URE. No evidence shows that URE or the ME have commissioned any expert reports or technical standards concerning SM. Overall, the government procurement can be regarded as a direct investment used in Poland for SM TIS development, although only to some extent.

\subsubsection{Economic and Financial Instruments-RD\&D Funding}

Five SM-related areas have been included in the Polish National Smart Specializations, which set priorities for RD\&D funding from the European Structural and Investment Funds in Poland. They include: (1) Digital measuring systems, including remote measuring systems (Advanced Metering Infrastructure-AMI) — new structures of AMI elements, technologies for communication and smart software for central AMI systems, interoperability and exchangeability of AMI elements; (2) Development of techniques and technologies of data transmission for the electricity industry needs; (3) Development of cybersecurity techniques-development of software, devices, and IT security services in the electricity sector; (4) Integration of measuring and reading systems for utilities (electricity, water, gas, heating), including the Smart Cities solution; and (5) Application of the Phasor Measurement Units (PMU) systems in transmission and distribution networks [74]. The main funding lines for RD\&D in the field of SM are national funds (National Fund for Environment Protection and Water Management) and EU funds (Smart Growth Operational Program, funded from the European Regional Development Fund and the Infrastructure and Environment Operational Program, funded from the European Regional Development Fund and the Cohesion Fund). However, even though SM is explicitly listed in Polish National Smart Specialization, only a few projects related to SM have been co-financed from the EU funds (7 projects with the key word 'SM' in the project title according to 
mapadotacjigov.pl database query as of July 2021 [75]). Additional national funding for RD\&D for SM projects was provided by the National Fund for Environment Protection and Water Management (NFOŚiGW) through the program "Smart Grids" in 2013. In response to the call, NFOŚiGW received 21 proposals requesting the total co-financing amount of $366.6 \mathrm{~m}$ PLN (approx. EUR $86 \mathrm{~m}$ ). As a result, 12 projects have been selected, with the total subsidy value of $171.9 \mathrm{~m}$ PLN (approx. EUR $40 \mathrm{~m}$ ) [76]. The beneficiaries of the program were: entrepreneurs, local government units, universities, research institutes, and the Polish Academy of Sciences and its organizational units. However, the funded research focused instead on power grid solutions other than SM.

Overall, RD\&D funding can be regarded as a direct investment instrument that is moderately used for SM TIS development in Poland.

\subsubsection{Economic and Financial Instruments-Tariffs}

Dynamic pricing tariffs have been regarded as fundamental measures for exploiting the full potential and benefits offered by SM since 2012 [71]. However, such instruments are still not legally possible in Poland.

On the other hand, any costs of SM system installation can be charged to the users indirectly, through energy tariffs. According to article 45 of the Energy Law, when calculating electricity prices covered by tariffs, the reasonable costs of the business activity of energy companies in the generation, processing, transmission, distribution, or trade of energy are taken into account. In particular, DSOs' return on capital approved in their tariff may significantly depend on parameters set by the President of URE, which have a certain degree of discretion and individuality for particular DSOs [77]. In 2011, this discretion was used by the regulator in the Position of URE President [78]. It was a major milestone that instigated the SM rollout in Poland, yet it was neither a formal regulation nor a legally binding decision. Nevertheless, the regulator announced that, due to the many benefits that SM implementation may bring, both to consumers and electricity companies, the President of URE is determined to apply extraordinary remuneration for such projects, which would be higher than the one expected for other investments of DSOs. Furthermore, the regulator declared that not only the investment effort would be rewarded in tariffs. Additionally, the individual actions of DSOs leading to increasing the benefits from the implementation would also be accepted by URE as justified costs in tariff approval procedures.

Considering this tariff-based support for the financing of SM rollouts in Poland, they can be regarded as financial instruments that are actively used in Poland to support SM TIS development.

\subsubsection{Economic and Financial Instruments-Grants and Subsidies}

Poland's government and its agencies have not provided any grants or subsidies for SM deployment, apart from the grants and subsidies for RD\&D projects described in the previous section. Overall, grants and subsidies can be regarded as financial instruments that are not widely used in Poland to support SM TIS development.

\subsubsection{Economic and Financial Instruments-Loans}

Even though no loan mechanisms dedicated specifically to the SM rollout have been identified in Poland, these types of financial instruments are used to support SM TIS development. For instance, thanks to the support of EUR $250 \mathrm{~m}$ from the European Fund for Strategic Investment, Energa, one of Poland's three largest electricity suppliers, has acquired EUR $750 \mathrm{~m}$ for the installation of SMs [79]. In this context, loans can be regarded as financial instruments used in Poland to support SM TIS development.

\subsubsection{Economic and Financial Instruments-Tax Relief/Exemption}

No tax relief or exemptions for the SM rollout have been identified in Poland [80]. Therefore, such instruments can be regarded as fiscal incentives not used in Poland to support SM TIS development. 


\subsubsection{Economic and Financial Instruments-User Charges}

According to $\$ 13$ point 4 of the Regulation of the Minister of Economy of 4 May 2007 on the detailed conditions for the operation of the power system [81], the DSO installs, at its own expense, the metering and billing systems, except for energy producers. Therefore, any direct user charges for SM systems are not legally allowed (except energy producers). In this context, user charges can be regarded as fiscal incentives not used in Poland to support SM TIS development.

\subsubsection{Economic and Financial Instruments-GHG Emission Allowance Trading Scheme}

In 2017, Poland sold GHG emission allowances worth over EUR 0.5 bn, while, in 2018, this value increased to over EUR 1 bn [82]. In 2019, it reached EUR 2.4 bn, and in 2020 it remained at a similar level (EUR 2.5 bn) $[83,84]$. However, there is no evidence that any share of these revenues has enabled the financing of SM TIS development. Therefore, the EU GHG emission allowance trading scheme can be regarded as a financial instrument for which there is no evidence that it is effectively used to support SM TIS development in Poland.

\subsubsection{Economic and Financial Instruments-White Certificates}

According to the Polish Law on Energy Efficiency, white certificates are tradable assets that can be awarded for the implementation of 'projects aimed to improve energy efficiency', which have been defined as activities consisting of introducing changes or improvements in a facility, in a technical device, or in an installation, as a result of which energy saving is achieved and positively audited [85]. Poland's white certificates scheme allows for granting certificates for measures indicated in the eligible energy-saving measures list published by the Minister of Energy [86]. However, the auditing guidelines do not allow for collecting evidence on the energy savings achieved directly thanks to SM deployment [87]. Therefore, no SM deployments can be considered as projects enabling the acquisition of white certificates. In this context, white certificates can be regarded as financial instruments that are not used to support SM TIS development in Poland.

\subsubsection{Soft Instruments-Endorsement Labels}

There is no evidence for the existence of any scheme for SM endorsement labels in Poland. There is also no evidence that any non-endorsement labels (labels discouraging SM installations) have gained wide popularity. Overall, endorsement labels can be regarded as soft instruments that are not effectively used to support SM TIS in Poland.

\subsubsection{Soft Instruments-Information Campaigns}

According to a public opinion survey performed in 2014, the most essential perceived benefit related to $\mathrm{SM}$ is greater control over consumption and expenses related to electricity, i.e., payment for actual electricity consumption instead of only estimates $(56.9 \%)$, lower electricity prices (41.9\%), and lower power consumption (41.4\%) [45]. Similarly, according to a public opinion survey performed in 2012 by GfK Polonia Research, $82 \%$ of Poles indicated that paying for actual electricity consumption is more important than the invariability of the electricity bill, and it is also the main advantage of remote reading meters [88]. On the other hand, the basic concerns related to the use of SM include fear of being charged with additional installation costs $(33.8 \%)$ and uncertainty related to the frequent failure of the new system (32\%).

Without changing the behavior of consumers, the costs incurred for the SM rollout may pay off over a longer time or, in extreme cases, not pay back at all [3]. In view of the low level of awareness regarding SM, DSOs and their organizations have initiated information campaigns. For instance, a nationwide information and education campaign entitled "Smart Grids-for home, environment, and economy", was organized by the PTPiREE in 2013 and 2014 in cooperation with DSOs, URE, the transmission system operator, and the Association of Energy Trading. The campaign included a range of educational activities 
in the field of rational and effective use of electricity using modern solutions in SGs, with particular emphasis on SM. The essential elements of the campaign were, among others: opinion polls, research and educational activities in demonstration buildings with SM installed, an educational campaign in the press, television and the Internet, distribution of information brochures, specialist training for meter installers and helpline staff, and a nationwide conference and experts' debates. The campaign was co-financed by the National Fund for Environmental Protection and Water Management [89].

In 2020, the Ministry of Climate started the project entitled "Intelligence in the energy sector. Support for the construction of smart grids in Poland", co-financed by the EU. The project assumes the implementation of a nationwide educational and information campaign and training on the functionalities of SMs and other related SG topics [90]. However, no data on the project progress or results are yet available.

Overall, information campaigns can be regarded as soft instruments that are used only to some extent to support SM TIS in Poland.

\subsubsection{Soft Instruments-Voluntary Approaches}

No unilateral commitments of the private sector (e.g., organization of DSOs), setting voluntary SM targets in Poland, have been identified. Therefore, voluntary schemes can be regarded as soft instruments that are not used to support SM TIS development in Poland.

\section{Discussion}

\subsection{DSOs as Major Innovating Actors}

Typically, the leading role in creating innovations, including in the stage of developing standards, is played by technology providers [91]. However, the Polish experiences in the market-driven rollout of SMs show that technology users (here: DSOs) may also have a critical function in these processes. A prime reason for this is that, unlike typical markets, power distribution is a specific type of oligopoly, including only a few companies, with a large part of ownership by the state. At least at first glance, they should have fairly uniform interests as well as risk appetite and risk aversion levels. However, our findings suggest that DSOs may react differently in response to the same signal of benevolence from the market regulator. This result could be explained by the fact that their expectations of benefits vary [34,52]. While the regulator's long-term vision was the necessary first step in starting the national rollout of SMs in Poland, the still low rates of SM penetration in the power grids of some of the Polish DSOs show that such signals may be insufficient for convincing more risk-averse stakeholders. Surprisingly, this observation holds even within the studied cost-plus tariff regime, which lowers the financial risks for the operators as compared to more market-based approaches.

Our findings illustrate well the contrasting examples of DSOs' expectations of benefits from SMs rollout. On the one hand, the limited activity of Enea in the SM deployment ties well with the previous studies that stress that network regulations need to be fine-tuned to ensure clean energy transition [92]. On the other hand, Energa's experiences show the opposite. Their high penetration rate of SMs suggest that, for some DSOs, only a small amount of assurance from the market regulator may be sufficient to initiate significant technological changes without modifying the pre-existing regulations.

\subsection{Knowledge Development and Exchange}

The major actors responsible for the SM deployment in Poland are ME, URE, and DSOs. However, these actors do not cooperate effectively. The Ministry has delayed the SM rollout obligation scheme for DSOs and has not approved the technical standards designed by the operators and their networks. Even though without initial incentivizing DSO investments by URE, the rollout would probably not start; over time the regulator became less active, leaving DSOs to develop and implement their individual rollout plans on their own [3]. Lack of cooperation increased the overall costs, as each DSO developed 
its procedures and standards. Still, some bottom-up collaboration initiatives emerged, e.g., joint procurements of SMs by three Polish DSOs.

The SM innovation system in Poland is characterized by relatively low-risk incremental innovation, as evidenced by the low number of patents in this technology area. The knowledge exchange is facilitated by PTPiREE and consultations on standards and procedures for SM installations. Similarly, the intensity of the creation of novel products and services is limited, as illustrated inter alia by the low interest of Polish firms and research organizations in acquiring EU and national funding for research, development, and demonstration projects. The knowledge exchange between science and industry is fair (e.g., the AMI picnic), although the exchange with the end-users of SMs (consumers) remains underexploited. Civil society is not actively involved in the SM rollout. Social awareness of SM is low, and the information campaigns that would inform customers about the benefits of SMs have been limited.

\subsection{Actors' Vision and Expectations}

The Polish SM rollout has been initiated due to the strong vision of the EU and Polish governmental stakeholders, as stated in the European Commission's proposal of the Electricity Directive Recast from 2007 (which led to the directive adoption in 2009) and in the URE President's position from 2010 [1,77]. Based on this shared vision of benefits and assurance of benevolence for SM investments by the regulator, DSOs have been taking up several individual initiatives in the field of SM, anticipating several types of benefits [34]. Still, due to the underdeveloped policy framework (Table 3), they do not expect to reach the government targets [38]. In this context, the visions of different actors within the innovation system are not aligned. Even though the expectations of benefits within the population of Polish DSOs are also not homogenous, they share a fairly common vision for SM technology in terms of its industrial design, as evidenced by the PTPIREE-proposed industrial standards.

\subsection{Market Formation and Governance Processes}

Similar to other markets around the world, such as Brazil [15], SM TIS in Poland is still in the early phase of development. It still requires some form of regulatory support, as evidenced by the fact that the market formation is relatively slow, even with the existing strong domestic SM production capacities. In line with the findings on SM diffusion in the Netherlands, the UK, Portugal, and Norway, the observed market formation involves struggles between policymakers and companies [13]. Our research shows that a more focused study, concentrating at the sub-national level of SM diffusion, provides significant additional insights into the dynamics of market-driven SM rollouts, allowing the study of different companies' reactions to the same policy framework (Figure 5). The Polish case illustrates that acceleration of SM diffusion relies not only on policy choices but also on the expectations of benefits by the market stakeholders. What is more, an active role of the national regulator (here illustrated by URE's anticipatory position of 2010 and its declared benevolence in approval of tariffs) can replace the policymakers in navigating the technology forcing described by Geels et al. [13], at least to some extent.

In a sense, our results also clarify and expand the findings of Schaechtele and Uhlenbrock [2], who claim that regulatory intervention is required not only for mandated SM rollouts but also for market-driven ones. The provided empirical evidence from the Polish case shows that, without binding regulatory intervention, the SM rollout may start and even be successful at the level of single DSOs. Still, to ensure that no one is left behind and the rollout progresses in a balanced way across the country, adequate and timely policy instruments need to be designed and applied by different relevant actors. 


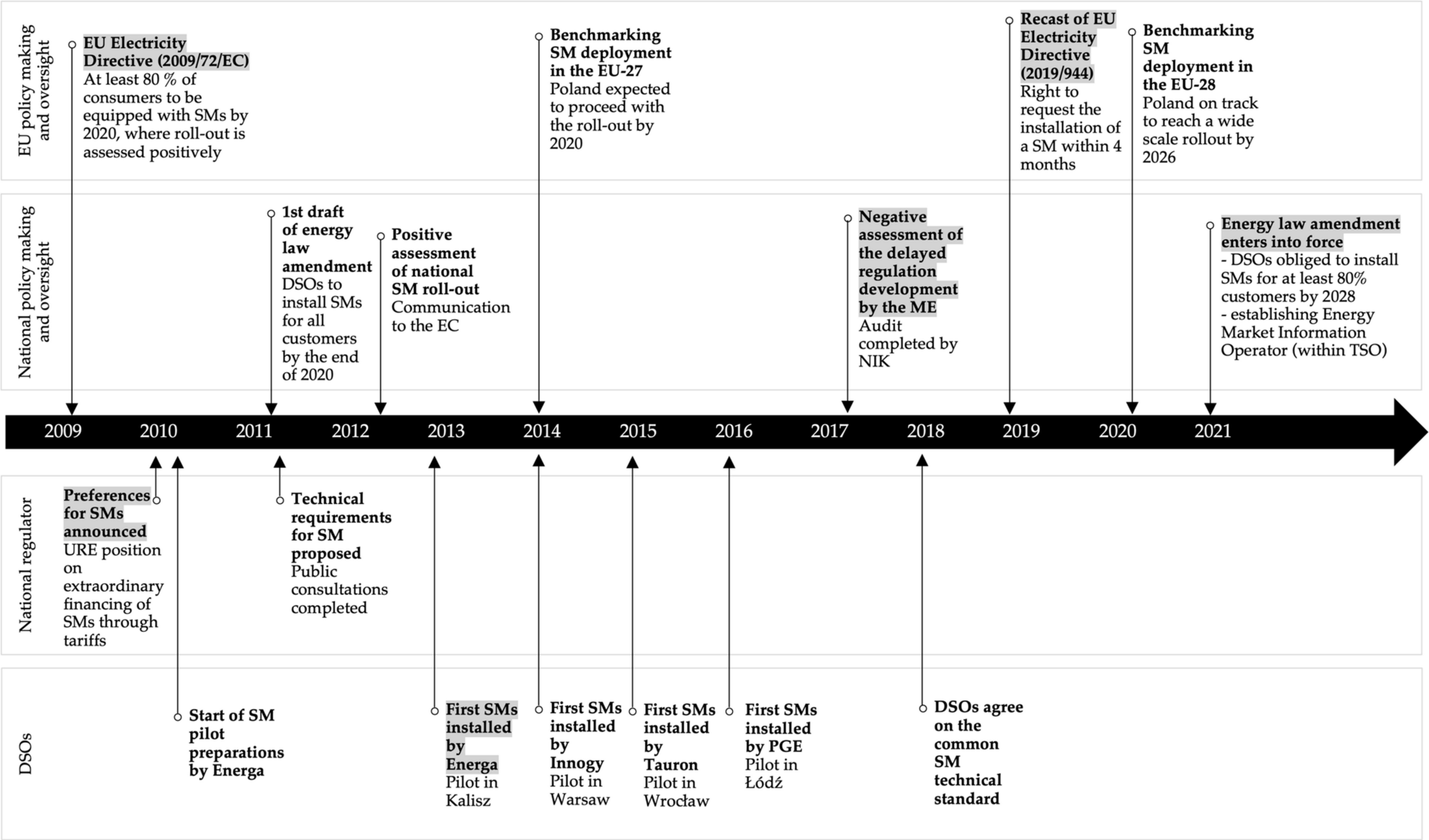

Figure 5. Timeline of market formation and governance processes in the SM rollout in Poland (2009-2021, major milestones highlighted in grey) [1,3,5,34,39,60,71,78,93-99]. 


\subsection{Resources, Costs and Sustainability}

High investment costs related to meter purchase and installation and the development of the surrounding infrastructure inhibit SM rollout. On the other hand, the strong SM production capacities may be seen as significant resources that accelerate innovation diffusion.

According to NIK, the installation of an SM is from 30\% to $66 \%$ more expensive than a traditional one [3]. ME estimated in 2013 that the total costs of the SM rollout program would be 3.85 bn PLN (EUR 0.91 bn) by 2026, while the expected net benefits would be 4.61 bn PLN (EUR 1.1 bn). Most of the costs are incurred by DSOs, mainly for meters, their installation, development of software, and system maintenance. The benefits, on the other hand, are gathered mainly after the rollout and are split between customers (18\%), suppliers (15\%), DSOs (29\%), and TSO (38\%) [4]. The delay in SM implementation results in the loss of benefits for all stakeholders. For households, the ME estimated that these were $78 \mathrm{~m}$ PLN (EUR §18.6 m) in 2017 and $117 \mathrm{~m}$ PLN (EUR $27.9 \mathrm{~m}$ ) in 2018 [3]. The poor state (age) of the Polish power infrastructure represents another barrier for the adoption of SMs. Replacement and upgrading of power grids to address the needs of growing distributed energy sources constitute a higher priority for the DSOs than the SM rollout, creating a significant sustainability dilemma that should also be addressed by the policymakers.

\subsection{Policy and Practice Recommendations}

The results of our analysis imply several policies and practical recommendations addressing SM policymakers, DSOs, and other stakeholders, which can facilitate and accelerate SM rollouts in Poland and beyond (Table 4). They can have implications for policy and practice, as they directly answer the call of the EC: "A system-wide approach is needed so digitalization of energy can help deliver on the EC's ambitious political priorities, including the European Green Deal and making the EU fit for the digital age" [100].

Table 4. Policy and practice recommendations addressing stakeholders of market-driven SM rollouts.

\begin{tabular}{|c|c|c|}
\hline $\begin{array}{l}\text { Stakeholder } \\
\text { Group }\end{array}$ & Recommendation & Justification \\
\hline \multirow{9}{*}{$\begin{array}{l}\text { Policy } \\
\text { makers }\end{array}$} & $\begin{array}{l}\text { Consider integration of SM requirements } \\
\text { in the building codes }\end{array}$ & $\begin{array}{l}\text { Building codes in Poland require installations of certain types of meters, e.g., water or electricity meters } \\
\text { (though not necessarily smart ones). It is recommended to consider providing similar requirements with } \\
\text { regard to SM installations in new buildings. }\end{array}$ \\
\hline & $\begin{array}{l}\text { Consider using Carbon Emissions } \\
\text { Reduction Target along with the SM } \\
\text { rollouts }\end{array}$ & $\begin{array}{l}\text { Carbon Emissions Reduction Target for DSO-driven SM rollouts could link the DSOs incomes from SM, } \\
\text { not necessarily with the number of SM installed, but rather with carbon emissions reductions resulting } \\
\text { from energy savings reached thanks to SM use by consumers due to behavior change. }\end{array}$ \\
\hline & $\begin{array}{l}\text { Continue investment in facilitating SM } \\
\text { rollouts through government } \\
\text { procurement and RD\&D funding }\end{array}$ & $\begin{array}{l}\text { The experiences of Poland clearly show that government procurement and RD\&D funding are effective } \\
\text { instruments of SM technology push, as demonstrated by the success story on OneMeter, a start-up } \\
\text { supported by the EU funds in Poland that developed beacons enabling SM functionalities in standard } \\
\text { electricity meters. It is recommended to continue investment in facilitating SM rollouts through such } \\
\text { policy instruments. }\end{array}$ \\
\hline & $\begin{array}{l}\text { Analyze the possibilities of introducing } \\
\text { tax reliefs or exemptions for SM } \\
\text { installations }\end{array}$ & $\begin{array}{l}\text { Due to expected positive externalities (energy savings), it is recommended to analyze the possibilities of } \\
\text { introducing tax incentives in the form of tax reliefs or exemptions that could boost foreign direct } \\
\text { investment as well as research and development. However, the related costs in terms of government } \\
\text { revenue loss and administrative overheads should be considered as well. }\end{array}$ \\
\hline & $\begin{array}{l}\text { Analyze the possibilities of introducing } \\
\text { user charges for SM installation and } \\
\text { operation instead of including the } \\
\text { SM-related costs in the grid charges } \\
\text { (tariffs) }\end{array}$ & $\begin{array}{l}\text { User charges for SM installation and operation may be considered as a better option than grid charges, } \\
\text { as the latter are available for the grid operators only, which excludes third-party metering point } \\
\text { operators from the market. Therefore, it is recommended to analyze the possibilities of introducing such } \\
\text { financial instruments in the SM financing model. }\end{array}$ \\
\hline & $\begin{array}{l}\text { Analyze the possibilities of using } \\
\text { revenues from GHG trading scheme for } \\
\text { the financing of SM rollouts }\end{array}$ & $\begin{array}{l}\text { The Directive 2003/87/EC stipulates that at least } 50 \% \text { of the revenues generated from the auctioning of } \\
\text { GHG allowances (or the equivalent in the financial value of these revenues) should be used to support } \\
\text { the achievement of specific climate and energy activities [101]. The list of objectives on which these } \\
\text { revenues should be spent includes, inter alia, energy efficiency. Therefore, it is recommended to consider } \\
\text { using this instrument for the financing of SM rollouts. }\end{array}$ \\
\hline & $\begin{array}{l}\text { Consider including SM rollouts as } \\
\text { measures eligible for issuing white } \\
\text { certificates }\end{array}$ & $\begin{array}{l}\text { White certificate schemes have been introduced in several EU Member States, including Poland [11]. } \\
\text { Still, the regulations underlying this financial mechanism do not consider SM rollouts as measures } \\
\text { eligible for issuing this type of tradeable assets. Therefore, it is recommended to consider the } \\
\text { possibilities of extending the list of eligible measures by adding the investments in SM systems. }\end{array}$ \\
\hline & Follow-up on results of auditing & $\begin{array}{l}\text { The experiences of the Polish auditing scheme of the SM rollout (comprehensive studies performed by } \\
\text { NIK) suggest that more focus of governmental bodies should be placed on the follow-up of auditors' } \\
\text { findings. Appropriate remedial, corrective, preventive, and improvement actions need to be } \\
\text { implemented according to auditing results to enable SM rollouts. }\end{array}$ \\
\hline & $\begin{array}{l}\text { Provide regular information on SM } \\
\text { penetration rate in the power grids }\end{array}$ & $\begin{array}{l}\text { Information on the progress of SM rollouts by different DSOs is usually either dispersed or published } \\
\text { incidentally (e.g., under NIK's reports in Poland). This limits the public oversight of the process and the } \\
\text { competition among different DSOs. Therefore, it is recommended to provide regular information on SM } \\
\text { penetration rate in power grids managed by different DSOs. }\end{array}$ \\
\hline
\end{tabular}


Table 4. Cont.

\begin{tabular}{|c|c|c|}
\hline $\begin{array}{l}\text { Stakeholder } \\
\text { Group }\end{array}$ & Recommendation & Justification \\
\hline \multirow{2}{*}{ DSOs } & $\begin{array}{l}\text { Combine SM rollouts with a tailor-made } \\
\text { set of soft measures addressing } \\
\text { preferences of individual end-users }\end{array}$ & $\begin{array}{l}\text { Prior research (e.g., [102]) shows that soft measures (e.g., information, advice) coupled with SM } \\
\text { installation can provide measurable energy savings in the residential sector. Therefore, it is } \\
\text { recommended that DSOs combine their SM rollouts with a tailor-made set of soft measures addressing } \\
\text { the preferences of their individual customers. }\end{array}$ \\
\hline & $\begin{array}{l}\text { Explore collaboration opportunities with } \\
\text { providers of BEMS to integrate SM with } \\
\text { other systems, allowing for empowering } \\
\text { users and energy savings }\end{array}$ & $\begin{array}{l}\text { As required by the Electricity Directive Recast [94], SM systems should allow for providing data for } \\
\text { consumer energy management systems. Therefore, it is recommended that DSOs explore collaboration } \\
\text { opportunities with providers of BEMS to integrate SM they install with other systems used by } \\
\text { consumers in order to empower them and facilitate achieving energy savings. }\end{array}$ \\
\hline \multirow{2}{*}{$\begin{array}{l}\text { Civil society } \\
\text { organisa- } \\
\text { tions, energy } \\
\text { agencies and } \\
\text { research or- } \\
\text { ganisations }\end{array}$} & $\begin{array}{l}\text { Collect and analyze evidence from SM } \\
\text { pilots on the benefits of SM rollouts for } \\
\text { different groups of stakeholders }\end{array}$ & $\begin{array}{l}\text { SM rollouts can provide various benefits for consumers, going beyond energy savings, such as } \\
\text { improvement in quality of service, facilitated acquisition of energy from renewables, improved control, } \\
\text { and more tariff and service options [103]. Other SM stakeholders, including DSOs, can also benefit, e.g., } \\
\text { from avoided costs of meter readings, demand response opportunities, and a better understanding of } \\
\text { customers' energy use. Still, the benefits actually achieved in SM rollouts need to be measured and } \\
\text { analyzed to encourage action from the SM sceptics or the uninformed. Therefore, it is recommended to } \\
\text { collect and analyze evidence from SM pilots on the benefits of SM rollouts for different groups } \\
\text { of stakeholders. }\end{array}$ \\
\hline & $\begin{array}{l}\text { Organize educational and awareness } \\
\text { raising campaigns informing consumers } \\
\text { about the benefits of SMs and their } \\
\text { potential integrations with } \\
\text { consumers' BEMS }\end{array}$ & $\begin{array}{l}\text { Communication with consumers and their engagement in the SM rollout should be regarded as } \\
\text { measures going beyond an information campaign. This should be considered as "a process with } \\
\text { multiple steps and activities that identifies the root obstacles to change and then nudges, motivates, or } \\
\text { enables people to behave in a different way" [103]. Therefore, given the relatively weak visibility of SM } \\
\text { awareness actions in Poland, it is recommended to organize educational and awareness raising } \\
\text { campaigns informing consumers about the benefits of SMs and their potential integrations with } \\
\text { consumers' BEMS. }\end{array}$ \\
\hline
\end{tabular}

\section{Conclusions}

The article has shown new evidence on the market-driven rollouts of Smart Metering, based on Technology Innovation System analysis for Poland. The country's experiences illustrate that the SM rollout may be successful at the level of single Distribution System Operators, even without binding regulatory intervention, because their expectations of benefits and the benevolence of regulators in tariff approval may be sufficient driving forces. Still, to ensure balanced rollout progress across the country, an adequate policy framework is necessary. The major push for SM TIS development in Poland comes from the energy industry, which started the pilot activities following the signal of benevolence from the regulator. A shared understanding of benefits from the SM implementation by the national market regulator and the EU policymakers was the main reason for starting the rollout. Pre-existing national policy instruments, such as tariffs enabling financing of SM systems and detailed public auditing of SM deployment processes, can be recognized as substantial factors accelerating SM TIS development. On the other hand, several barriers to the SM rollout are present in the policy instruments landscape, including inexistent, legally binding national SM standards. The limited supporting and coordinating role of the government can be considered as another barrier. This passive role entailed delaying large-scale SM deployment and decreasing the benefits available for customers. Furthermore, lack of the precise EU-level or national standardization framework encouraged the DSOs to introduce their own set of regulations, which have not been validated or certified by any public authority, e.g., for cybersecurity or interoperability conformance with relevant standards.

Our assessment on the outlook for SM in Poland is moderately positive. While the first phase of the rollout was driven mainly by one DSO, the recently introduced obligation scheme can be a sufficient motivating factor for the companies that were skeptical towards introduction of SM. A few critical issues will decide whether the SM implementation is successful. First, it is yet to be seen whether the obligation scheme, without clear incentives and penalties for the DSOs for reaching the targets set by the government, will be effective. Second, because the introduced obligation scheme is formulated in isolation from targets on energy savings, the potential energy efficiency improvements due to the SM introduction will mostly rely on the DSOs' voluntary activities in the field of soft measures.

Several limitations and implications for further studies are also apparent in the performed research. The qualitative approach utilized in this research suffers from inevitable subjectivity. To minimize the impact of this limitation on the research quality, we avoided providing opinions or assessments that would not be supported with relevant justifications 
and references. This limitation might be further addressed in future research, e.g., involving a multi-stakeholder expert panel to assess different policy instruments applicable for stimulating SM rollouts.

Author Contributions: Conceptualization, M.K. and T.S.; methodology, M.K. and T.S.; validation, T.S. and K.K.; investigation, M.K. and K.K.; resources, T.S.; data curation, M.K.; writing—original draft preparation, M.K.; writing—review and editing, K.K. and T.S.; visualization, M.K.; supervision, T.S.; project administration, T.S.; funding acquisition, T.S. All authors have read and agreed to the published version of the manuscript.

Funding: The article has been prepared under the projects: (1) INNOPATHS: Innovation pathways, strategies and policies for the Low-Carbon Transition in Europe. The project has received funding from the European Union's Horizon 2020 research and innovation program under grant agreement No. 730403; (2) NEWTRENDS: New trends in energy demand modeling. The project has received funding from the European Union's Horizon 2020 research and innovation program under grant agreement No. 893311.

Institutional Review Board Statement: Not applicable.

Informed Consent Statement: Not applicable.

Data Availability Statement: Not applicable.

Conflicts of Interest: The authors declare no conflict of interest.

\section{Glossary}

\begin{tabular}{|c|c|}
\hline AMI & Advanced Metering Infrastructure \\
\hline BAS & Building Automation System \\
\hline CSIRE & $\begin{array}{l}\text { Central Energy Market Information System } \\
\text { (in Polish: Centralny System Informacji o Rynku Energii) }\end{array}$ \\
\hline DSO & Distribution System Operator \\
\hline EC & European Commission \\
\hline EU & European Union \\
\hline GHG & Greenhouse Gas \\
\hline HAN & Home Area Network \\
\hline ICT & Information and Communication Technologies \\
\hline ME & $\begin{array}{l}\text { Ministry responsible for Energy } \\
\text { (in Polish: Minister właściwy ds. Energii) }\end{array}$ \\
\hline NIK & $\begin{array}{l}\text { Supreme Audit Office } \\
\text { (in Polish: Najwyższa Izba Kontroli) }\end{array}$ \\
\hline OBIS & Object Identification System \\
\hline PLN & Polish zloty \\
\hline PTPiREE & $\begin{array}{l}\text { Polish Electricity Transmission and Distribution Association } \\
\text { (in Polish: Polskie Towarzystwo Przesyłu i Rozdziału Energii Elektrycznej) }\end{array}$ \\
\hline RD\&D & Research, Development and Demonstration \\
\hline SGs & Smart Grids \\
\hline SM & Smart Meter/Smart Metering \\
\hline TIS & Technology Innovation System \\
\hline TSO & Transmission System Operator \\
\hline UKE & $\begin{array}{l}\text { Office of Electronic Communications } \\
\text { (in Polish: Urząd Komunikacji Elektronicznej) }\end{array}$ \\
\hline URE & $\begin{array}{l}\text { Energy Regulatory Office } \\
\text { (in Polish: Urząd Regulacji Energetyki) }\end{array}$ \\
\hline WAN & Wide Area Network \\
\hline
\end{tabular}




\section{References}

1. European Parliament; Council of the European Union. Directive 2009/72/EC of 13 July 2009 Concerning Common Rules for the Internal Market in Electricity and Repealing Directive 2003/54/EC; European Parliament and Council of the European Union: Brussels, Belgium, 2009; Volume L 211/55.

2. Schaechtele, J.; Uhlenbrock, J. How to Regulate a Market-Driven Rollout of Smart Meters? A Multi-Sided Market Perspective. SSRN Electron. J. 2012, 1-30. [CrossRef]

3. Supreme Audit Office. Wystapienie Pokontrolne P/17/022-Ochrona Praw Konsumentów Energii Elektrycznej (Audit Report P/17/022Protection of the Rights of Electricity Consumers); Supreme Audit Office: Warsaw, Poland, 2018. (In Polish)

4. Ministry of Economy. Analiza Skutków Społeczno-Gospodarczych Wdrożenia Inteligentnego Opomiarowania (Analysis of the SocioEconomic Effects of Implementing Smart Metering); Ministry of Economy: Warsaw, Poland, 2013. (In Polish)

5. European Commission. Benchmarking Smart Metering Deployment in the EU-28; European Commission: Brussels, Belgium, 2020.

6. Smart Energy International. Market Driven Smart Meter Rollouts. Available online: https://www.smart-energy.com/magazinearticle/market-driven-smart-meter-rollouts / (accessed on 28 July 2021).

7. Energy Retailers Association of Australia. Enabling a Market-Driven Smart Meter Rollout. Available online: https: / / www.aer.gov.au/system/files/ERAA\%20-\%20Report\%20supporting\%20submission\%20-\%20ERAA\%27s\%20Marketdriven\%20smart\%20meter\%20rollout\%20paper\%20-\%20September\%202012.pdf (accessed on 28 July 2021).

8. Sial, A.; Singh, A.; Mahanti, A. Detecting anomalous energy consumption using contextual analysis of smart meter data. Wirel. Netw. 2019, 27, 4275-4292. [CrossRef]

9. Sial, A.; Singh, A.; Mahanti, A.; Gong, M. Heuristics-Based Detection of Abnormal Energy Consumption. In Smart Grid and Innovative Frontiers in Telecommunications. SmartGIFT 2018. Lecture Notes of the Institute for Computer Sciences, Social Informatics and Telecommunications Engineering; Chong, P., Seet, B.C., Chai, M., Rehman, S., Eds.; Springer: Cham, Switzerland, 2018 ; Volume 245. [CrossRef]

10. Sial, A.; Jain, A.; Singh, A.; Mahanti, A. Profiling Energy Consumption in a Residential Campus. In Proceedings of the 2014 CoNEXT on Student Workshop (CoNEXT Student Workshop '14, Sydney, Australia, 2 December 2014); Association for Computing Machinery: New York, NY, USA, 2014; pp. 15-17. [CrossRef]

11. Kochański, M.; Korczak, K.; Skoczkowski, T. Technology Innovation System Analysis of Electricity Smart Metering in the European Union. Energies 2020, 13, 916. [CrossRef]

12. Spodniak, P.; Jantunen, A.; Viljainen, S. Diffusion and drivers of smart meters: The case of Central and Eastern Europe. Int. J. Innov. Technol. Manag. 2014, 11, 1-16. [CrossRef]

13. Geels, F.W.; Sareen, S.; Hook, A.; Sovacool, B.K. Navigating implementation dilemmas in technology-forcing policies: A comparative analysis of accelerated smart meter diffusion in the Netherlands, UK, Norway, and Portugal (2000-2019). Res. Policy 2021, 50, 104272. [CrossRef]

14. Zhou, S.; Brown, M.A. Smart meter deployment in Europe: A comparative case study on the impacts of national policy schemes. J. Clean. Prod. 2017, 144, 22-32. [CrossRef]

15. Carvalho, P. Smart metering deployment in Brazil. Energy Procedia 2015, 83, 360-369. [CrossRef]

16. Järventausta, P. Smart Grids with Large-Scale Implementation of Automatic Meter Reading: Experiences from Finland. In Handbook of Clean Energy Systems; John Wiley \& Sons, Ltd.: Chichester, UK, 2015; pp. 1-8.

17. Gordon, J.A. Hungary's Disconnect from a Smart Energy Reality: Can a Weak Waverer Become a Determined Driver in the EU Smart Metering Landscape? Central European University: Budapest, Hungary, 2019. [CrossRef]

18. Balasubramanya, C. Challenges in Adoption of International Model of Consumer Protection in India for Mass Roll Out of Smart Energy Meters-Indian Journals. Power Eng. J. 2014, 16, 50-55.

19. AlAbdulkarim, L.O.; Lukszo, Z. Smart metering for the future energy systems in the Netherlands. In Proceedings of the 2009 4th International Conference on Critical Infrastructures, Linköping, Sweden, 27 March-30 April 2009; IEEE: New York, NY, USA, 2009.

20. Hoenkamp, R.; Huitema, G.B.; De Moor-van Vugt, A.J.C. The Neglected Consumer: The Case of the Smart Meter Rollout in the Netherlands. JSTOR. Renew. Energy Law Policy Rev. 2011, 2, 269-282. [CrossRef]

21. Chawla, Y.; Kowalska-Pyzalska, A.; Silveira, P.D. Marketing and communications channels for diffusion of electricity smart meters in Portugal. Telemat. Inform. 2020, 50, 101385. [CrossRef]

22. Redl, C.; Hein, F.; Buck, M.; Graichen, P.; Jones, D. The European Power Sector in 2020. Up-to-Date Analysis on the Electricity Transition. Analysis. Available online: https://ember-climate.org/wp-content/uploads/2021/01/Report-European-PowerSector-in-2020.pdf (accessed on 28 July 2021).

23. Derski, B. Źródła Energii w Polsce w 2020: Mniej Węgla, Więcej Gazu i OZE (Energy Sources in Poland in 2020: Less Coal, More Gas and RES). Available online: https:/ / wysokienapiecie.pl/35619-zrodla-energii-w-polsce-w-2020-mniej-wegla-wiecej-gazu-oze/ (accessed on 28 July 2021). (In Polish)

24. Gramwzielone.pl Liczba Prosumentów w Polsce Przekroczyła Pół Miliona (The Numer of Prosumers in Poland has Exceeded 0.5 Million). Available online: https://www.gramwzielone.pl/energia-sloneczna/105406/liczba-prosumentow-w-polsceprzekroczyla-pol-miliona (accessed on 28 July 2021). (In Polish)

25. Energy Regulatory Office. Charakterystyka Rynku Energii Elektrycznej 2017. Available online: https://www.ure.gov.pl/pl/ rynki-energii/energia-elektryczna/charakterystyka-rynku/7562,2017.html (accessed on 28 July 2021). (In Polish) 
26. Polskie Sieci Elektroenergetyczne System in General. Available online: https://www.pse.pl/web/pse-eng/areas-of-activity / polish-power-system/system-in-general (accessed on 20 August 2021).

27. Tomaszewski, R. Sieć do Zmiany. Jak Zreformować Polski Sektor Dystrybucji Energii Elektrycznej (The Grid to Change. How to Reform the Polish Electricity Distribution Sector). Available online: https://www.politykainsight.pl/prawo/_resource/ multimedium/20182100 (accessed on 28 July 2021). (In Polish)

28. Skoczkowski, T.; Verdolini, E.; Bielecki, S.; Kochański, M.; Korczak, K.; Węglarz, A. Technology Innovation System analysis of decarbonisation options in the EU steel industry. Energy 2020, 212, 118688. [CrossRef] [PubMed]

29. Peñasco, C.; Verdolini, E.; Larkin, P. INNOPATHS Prototype of Policy Evaluation Tool; INNOPATHS: Cambridge, UK, 2018.

30. Statistics Poland. Produkcja Wyrobów Przemystowych w 2016 Roku (Production of Industrial Products in 2016); Statistics Poland: Warsaw, Poland, 2017. (In Polish)

31. Statistics Poland. Produkcja Wyrobów Przemystowych w 2018 Roku (Production of Industrial Products in 2018); Statistics Poland: Warsaw, Poland, 2019. (In Polish)

32. Statistics Poland. Produkcja Wyrobów Przemysłowych w 2019 Roku (Production of Industrial Products in 2019); Statistics Poland: Warsaw, Poland, 2020. (In Polish)

33. Lewczuk, Ł. Do Pomiaru Poboru Energii-Liczniki Energii Elektrycznej (For Measuring Energy Consumption—Electricity Meters). Available online: http:/ / www.fachowyelektryk.pl/technologie/zasilanie/2070-do-pomiaru-poboru-energii-licznikienergii-elektrycznej.html (accessed on 3 January 2020). (In Polish).

34. Energa-Operator SA. Podsumowanie Pierwszego Etapu Wdrożenia Systemu Inteligentnego Opomiarowania (Summary of the First Stage of Smart Metering System Implementation); Energa Operator: Gdańsk, Poland, 2014. (In Polish)

35. Ministry of Climate and Environment. Uzasadnienie do Rzadowego Projektu Ustawy o Zmianie Ustawy-Prawo Energetyczne Oraz Niektórych Innych Ustaw. (Druk nr 808) (Justification for the Government Bill Amending the Energy Law and Certain Other Acts. (Print No. 808)); Ministry of Climate and Environment: Warsaw, Poland, 2020. (In Polish)

36. PAP. Apator Chce Utrzymać Udział w Rynku Dostaw Liczników Inteligentnych w Polsce (Apator Wants to Maintain the Share in the Market of Supplies of Smart Meters in Poland). Available online: https:/ /www.bankier.pl/wiadomosc/Apator-chceutrzymac-udzial-w-rynku-dostaw-licznikow-inteligentnych-w-Polsce-8090021.html (accessed on 28 July 2021). (In Polish).

37. Minister of Entrepreneurship and Technology. Rozporzadzenie Ministra Przedsiębiorczości i Technologii z Dnia 22 Marca 2019 r. w Sprawie Prawnej Kontroli Metrologicznej Przyrzadów Pomiarowych (Dz. U. 2019 poz. 759) (Regulation of the Minister of Entrepreneurship and Technology of March 22, 2019 on Legal Metrological Control of Measuring Equipment (Journal of Laws 2019 pos. 759); Minister of Entrepreneurship and Technology: Warsaw, Poland, 2019. (In Polish)

38. CIRE. Liczniki Smart, Jak to Wygląda? (Smart Meters, What Does It Look Like?). Available online: https:// biznesalert.pl/licznikismart-jak-to-wyglada/ (accessed on 28 July 2021). (In Polish).

39. PTPiREE. Wymagania Techniczne dla Statycznych Bezpośrednich 1-Fazowych Liczników Energii Elektrycznej (Technical Requirements for Static Direct 1-Phase Electricity Meters); PTPiREE: Warsaw, Poland, 2018. (In Polish)

40. Polish Committee for Standardization. PN-EN 62056-6-1:2018-02-Wersja Angielska. Wymiana Danych w Pomiarach Energii Elektrycznej-Zespót DLMS/COSEM-Część 6-1: System Identyfikacji Obiektów (OBIS); Polish Committee for Standardization: Warsaw, Poland, 2018. (In Polish)

41. Apator. Karta Techniczna: SMART EMU 3 Trójfazowy Licznik Energii Elektrycznej (Technical Card: SMART EMU 3 Three-Phase Electricity Meter); Apator: Torun, Poland, 2014. (In Polish)

42. ADD Grup. AD13A.1-3-1 Multi-Function \& Multi-Tariff Three-Phase Electronic Meters; ADD Grup: Chisinau, Republic of Moldova, 2017.

43. ADD Grup. Rtr8s.lx-x-x Data Concentrator Technical Description; ADD Grup: Chisinau, Republic of Moldova, 2017.

44. PTPiREE. Wymagania Bezpieczeństwa Wobec Statycznych Bezpośrednich 1-Fazowych i 3-Fazowych Liczników Energii Elektrycznej (Security Requirements for Static Direct 1-Phase and 3-Phase Electricity Meters); PTPiREE: Warsaw, Poland, 2018. (In Polish)

45. Procontent Communication; SW Research. Wiedza Polaków na Temat Inteligentnych Liczników—Raport z Badania (Knowledge of Poles on Smart Meters-Report from the Study); Procontent Communication \& SW Research: Warsaw, Poland, 2014. (In Polish)

46. Sobolak, J. Wielka Wymiana Liczników Prądu w Polskich Domach. Kto za to Zapłaci? (Great Replacement of Electricity Meters in Polish Homes. Who Will Pay for It?). Available online: https: / www.money.pl/gospodarka/wielka-wymiana-licznikowpradu-w-polskich-domach-kto-za-to-zaplaci-6637141500955584a.html (accessed on 28 July 2021). (In Polish)

47. Zamorowska, K. Inteligentne Liczniki-Cała Europa Wdraża, ale z Różnym Skutkiem (Smart Meters—All of Europe Are Implementing, But with Varying Success). Available online: https://www.teraz-srodowisko.pl/aktualnosci/inteligentneliczniki-cala-europa-wdraza-6796.html (accessed on 28 July 2021). (In Polish)

48. Energa-Operator SA. Zamontowane Inteligentne Liczniki (stan na dzień: 30.06.2021) (Installed Smart Meters (as at: 30/06/2021)). Available online: https://energa-operator.pl/infrastruktura/liczniki-zdalnego-odczytu/zamontowane (accessed on 28 July 2021). (In Polish)

49. ISBNews. Tauron Wymienia Analogowe Liczniki na te ze Zdalnym Odczytem Poboru Energii (Tauron Replaces Analog Meters with Those with Remote Reading of Energy Consumption). Available online: https:/ forsal.pl/biznes/energetyka/artykuly/80 68740, tauron-wymienia-analogowe-liczniki-na-te-ze-zdalnym-odczytem-energii.html (accessed on 28 July 2021). (In Polish) 
50. Ciepiela, D. Ilu Klientów Mają Najwięksi Dystrybutorzy Energii? (How Many Customers Do the Largest Energy Distributors Have?). Available online: https://www.wnp.pl/energetyka/ilu-klientow-maja-najwieksi-dystrybutorzy-energii,445840.html (accessed on 28 July 2021). (In Polish)

51. Skoczkowski, T.; Kochański, M. Some aspects of the growing penetration of wind energy in the Polish power system. Prz. Elektrotech. 2013, 89, 94-99.

52. Ciepiela, D. P. Zaleski, Enea Operator: Inteligentne Liczniki Energii Nie Zawsze Są Opłacalne (P. Zaleski, Enea Operator: Smart Energy Meters Are Not Always Profitable). Available online: https:/ /www.elektryka.org/artykuly/szczegoly/635_p-zaleskienea-operator-inteligentne-liczniki-energii-nie-zawsze-sa-oplacalne (accessed on 28 July 2021). (In Polish)

53. Apator. Beneficjenci Transformacji Energetycznej (Beneficiaries of the Energy Transformation); Apator: Torun, Poland, 2021. (In Polish)

54. Science and Technology Park Euro-Centre. Rynek Inteligentnych Sieci Energetycznych w Polsce (Market of Smart Grids in Poland); Science and Technology Park Euro-Centre: Katowice, Poland, 2013. (In Polish)

55. ElektronikaB2B. Apator Wprowadza w Warszawie Inteligentne Liczniki Energii (Apator Introduces Smart Meters in Warsaw). Available online: https:/ / elektronikab2b.pl/biznes/51304-apator-wprowadza-w-warszawie-inteligentne-liczniki-energii (accessed on 19 April 2020). (In Polish)

56. Akademia Górniczo-Hutnicza; Politechnika Wrocławska; Tauron Dystrybucja S.A. Badania Porównawcze Inteligentnych Liczników Energii Elektrycznej-Pikinik AMI (Benchmarking Tests of Smart Electricity Metres-AMI Picnic); Akademia Górniczo-Hutnicza: Kraków, Poland; Politechnika Wrocławska: Wrocław, Poland; Tauron Dystrybucja S.A.: Kraków, Poland, 2016. (In Polish)

57. Ministry of Energy. Serwis Rzeczypospolitej Polskiej (Homepage of the Republic of Poland). Available online: https://www.gov. pl/web/energy (accessed on 18 April 2019). (In Polish)

58. Energy Regulatory Office. President's Duties. Available online: https://www.ure.gov.pl/en/about-us/presidents-duties/22 ,Presidents-duties.html (accessed on 18 April 2019).

59. PIIT. Stanowisko Polskiej Izby Informatyki i Telekomunikacji w Sprawie Wymagań dla Liczników Energii Elektrycznej Opracowanych przez Polskie Towarzystwo Przesyłu i Rozdziału Energii Elektrycznej (The Position of the Polish Chamber of Information Technology and Telecommunications on the Requirements for Electricity Meters Developed by the Polish Association for the Transmission and Distribution of Electricity); PIIT: Warsaw, Poland, 2018. (In Polish)

60. Sejm Rzeczpospolitej Polskiej. Ustawa z dn. 20 Maja 2021 r. o Zmianie Ustawy-Prawo Energetyczne Oraz Niektórych Innych Ustaw (Dz. U. 2021 poz. 1093) (Act of May 20, 2021 Amending the Energy Law and Certain Other Acts (Journal of Laws 2021 Item 1093 )); Sejm Rzeczypospolitej Polskiej: Warsaw, Poland, 2021; pp. 1-52. (In Polish)

61. Bank Ochrony Środowiska. Ecological Report of Bank Ochrony Środowiska 2017/2018; Bank Ochrony Środowiska: Warsaw, Poland, 2018.

62. Bank Ochrony Środowiska. O Banku (About the Bank). Available online: https://www.bosbank.pl/o-banku/kim-jestesmy (accessed on 18 April 2019). (In Polish)

63. Narodowy Fundusz Ochrony Środowiska i Gospodarki Wodnej. Inteligentne Sieci Energetyczne (Smart Grids). Available online: http://nfosigw.gov.pl/oferta-finansowania/srodki-krajowe/programy/inteligentne-sieci-energetyczne/ (accessed on 18 April 2019). (In Polish)

64. Minister Infrastruktury i Rozwoju. Obwieszczenie Ministra Infrastruktury i Rozwoju z Dnia 17 Lipca 2015 r. Załacznik: Rozprzadenie Ministra Infrastruktury z Dnia 12 Kwietnia 2002 r. w Sprawie Warunków Technicznych Jakim Powinny Odpowiadać Budyniki i ich Usystowanie (Announcement of the Minister of Infrastructure and Development of 17 July 2015. Annex: Regulation of the Minister of Infrastructure of 12 April 2002 on Technical Conditions to Be Met by Buildings and Their Arrangement); Minister Infrastruktury i Rozwoju: Warsaw, Poland, 2015. (In Polish)

65. European Parliament; Council of the European Union. Directive 2014/32/EU of the European Parliament and of the Council of 26 February 2014 on the harmonisation of the Laws of the Member States Relating to the Making Available on the Market of Measuring Instruments (Recast); European Parliament: Brussels, Belgium; Council of the European Union: Brussels, Belgium, 2014.

66. Tauron Dystrybucja. Wymagania do SIWZ i Umowy dla Statycznych Bezpośrednich 1 i 3 Fazowych Liczników Energii Elektrycznej dla Postępowań Ogłoszonych od 2021 Roku-Wersja 2 (Requirements to the Terms of Reference and the Agreement for Static Direct 1 and 3-Phase Electricity Metres for Proceedings Announced Starting from 2021); Tauron Dystrybucja S.A.: Kraków, Poland, 2021. (In Polish)

67. Energy Regulatory Office. Rekomendowane Zapisy Specyfikacji Istotnych Warunków Zamówienia Opracowane dla Postępowań Przetargowych na Dostawę Infrastruktury Licznikowej dla Systemów AMI (Recommended Provisions of the Specification of Essential Terms of the Contract Developed for Tendering Procedures for the Supply of Meter Infrastructure for AMI). Available online: http:/ / ise.ure.gov.pl/ise/warsztaty-rynku-energi/ami/6170,Rekomendowane-zapisy-specyfikacji-istotnych-warunkowzamowienia-opracowane-dla-p.html (accessed on 29 July 2021). (In Polish)

68. Polish Chamber of Commerce for Electronics and Telecommunications. Wymagania Techniczne i Eksploatacyjne dla Liczników 1-i 3-Fazowych Przeznaczonych Do Pracy w Polskich Systemach AMI (Technical and Performance Requirements for 1-and 3-Phase Meters Designed for Operation in Polish AMI Systems); Polish Chamber of Commerce for Electronics and Telecommunications: Warsaw, Poland, 2016.

69. Tauron Dystrybucja SA. Zakończono Konsultacje Dokumentu “Projekt Wymagań Technicznych dla Statycznych Bezpośrednich Liczników Energii Elektrycznej" (Consultations on the Document Entitled "Draft Technical Requirements for Static Direct Electricity Metres" Have Been Completed). Available online: https://www.tauron-dystrybucja.pl/o-spolce/aktualnosci/2018/0 9/2018-09-21 (accessed on 21 November 2018). (In Polish) 
70. Sejm Rzeczpospolitej Polskiej. Law of May 10, 2018 on Personal Data Protection; Sejm Rzeczpospolitej Polskiej: Warsaw, Poland, 2018; pp. 1-10. (In Polish)

71. Swora, M. Infrastruktura Sieci Domowej (ISD) w Ramach Inteligentnych Sieci/HAN within Smart Grids (Home Network Infrastructure (ISD) within Smart Grids/HAN within Smart Grids); Energy Regulatory Office: Warsaw, Poland, 2012. (In Polish)

72. Sejm Rzeczpospolitej Polskiej. Law on Renewable Energy Sources; Journal of Laws of 2017, pos. 1148; Sejm Rzeczpospolitej Polskiej: Warsaw, Poland, 2018. (In Polish)

73. European Commission. TED Tenders Electronic Daily. Available online: https://ted.europa.eu/ (accessed on 22 November 2020).

74. Ministry of Development. Polish National Smart Specializations; ver. 3; Ministry of Development: Warsaw, Poland, 2017. (In Polish)

75. Ministry of Funds and Regional Policy. Mapa Dotacji UE (EU Grants Map); Ministry of Funds and Regional Policy: Warsaw, Poland, 2021.

76. Narodowy Fundusz Ochrony Środowiska i Gospodarki Wodnej. Dobry Klimat dla Środowiska; Narodowy Fundusz Ochrony Środowiska i Gospodarki Wodnej: Warsaw, Poland, 2013. (In Polish)

77. Przybył, M.A.; Śpiewak, R. Oddziaływanie regulatora na czynniki finansowe operatorów systemu dystrybucyjnego energii elektrycznej (The regulator's impact on the financial factors of electricity distribution system operators). Energy Policy J. 2017, 20, 89-104. (In Polish)

78. Energy Regulatory Office. Stanowisko Prezesa URE w Sprawie Niezbędnych Wymagań wobec Wdrażanych Przez OSD E Inteligentnych Systemów Pomiarowo-Rozliczeniowych z Uwzględnieniem Funkcji Celu oraz Proponowanych Mechanizmów Wsparcia przy Postulowanym Modelu Rynku (The Position of the President of the ERO on the Necessary Requirements for the Intelligent Metering and Billing Systems Implemented by DSO E, Taking into Account the Objective Function and Proposed Support Mechanisms for the Proposed Market Model); Energy Regulatory Office: Warsaw, Poland, 2011. (In Polish)

79. European Commission. Investment Plan Results. Available online: https://ec.europa.eu/commission/priorities/jobs-growthand-investment/investment-plan-europe-juncker-plan/investment-plan-results/ (accessed on 2 May 2019).

80. Kochański, M. Identification and quantification of the fiscal effects of electricity generation in Poland. Acta Innov. 2016, 21, 71-80.

81. Ministry of Economy. Rozporzadzenie Ministra Gospodarki z Dnia 4 Maja 2007 r. w Sprawie Szczegótowych Warunków Funkcjonowania Systemu Elektroenergetycznego (Ordinance of the Minister of Economy of May 4, 2007 on the Detailed Conditions for the Operation of the Power System); Ministry of Economy: Warsaw, Poland, 2007; pp. 6477-6507. (In Polish)

82. Biznes Alert. Już Ponad Miliard Euro Przychodów ze Sprzedaży Uprawnień do Emisji $\mathrm{CO}_{2}$ (Already over a Billion Euro of Revenues from the Sale of $\mathrm{CO}_{2}$ Emission Allowances). Available online: http:/ /biznesalert.pl/emisje-co2-sprzedaz-przychody/ (accessed on 15 April 2019). (In Polish).

83. Skłodowska, M.; Zasuń, R. Fiskus Zarobił Kolejne Miliardy na $\mathrm{CO}_{2}$ (The Tax Office Has Made Billions More on $\mathrm{CO}_{2}$ ). Available online: https: / wysokienapiecie.pl/24780-fiskus-zarobil-kolejne-miliardy-na-co2/ (accessed on 28 July 2021). (In Polish)

84. Derski, B. Ceny $\mathrm{CO}_{2}$ Rekordowo Wysokie. Budżet Zarobił $12 \mathrm{Mld}$ zł $\left(\mathrm{CO}_{2}\right.$ Prices Are Record High. The Budget Earned PLN 12 Billion). Available online: https://wysokienapiecie.pl/34903-ceny-co2-rekordowo-wysokie-budzet-zarobil-12-mld-zl/ (accessed on 28 July 2021). (In Polish)

85. Sejm Rzeczpospolitej Polskiej. Law on Energy Efficiency, (Dz.U. 2016 poz. 831); Sejm Rzeczpospolitej Polskiej: Warsaw, Poland, 2016. (In Polish)

86. Rosenow, J.; Skoczkowski, T.; Thomas, S.; Węglarz, A.; Stańczyk, W.; Jędra, M. Evaluating the Polish White Certificate scheme. Energy Policy 2020, 144, 111689. [CrossRef]

87. Ministry of Energy. Rozporządzenie Ministra Energii z Dnia 5 Października 2017 r. w Sprawie Szczegótowego Zakresu I Sposobu Sporządzania Efektywności Energetycznej oraz Metod Obliczania Oszczędności Energii (Regulation of the Minister of Energy of October 5, 2017 on the Detailed Scope and Method of Preparing Energy Efficiency and Methods of Calculating Energy Savings); Ministry of Energy: Warsaw, Poland, 2017. (In Polish)

88. Energy Regulatory Office. Odejście od Prognoz Rachunków Główną Zaletą Liczników Inteligentnych (No Bill Forecasts Is the Main Advantage of Smart Metres). Available online: https://www.ure.gov.pl/pl/urzad/informacje-ogolne/aktualnosci/5260 ,Odejscie-od-prognoz-rachunkow-glowna-zaleta-licznikow-inteligentnych.html (accessed on 28 July 2021). (In Polish)

89. PTPiREE. Kampanie Informacyjne. Available online: http:/ / www.ptpiree.pl/nasza-dzialalnosc/kampanie-informacyjne (accessed on 4 February 2019). (In Polish)

90. Ministry of Climate and Environment. Rozwój Inteligentnych Sieci Energetycznych Jednym z Priorytetów Ministerstwa Klimatu (The Development of Smart Energy Networks Is One of the Priorities of the Ministry of Climate). Available online: https: //www.gov.pl/web/klimat/rozwoj-inteligentnych-sieci-energetycznych-jednym-z-priorytetow-ministerstwa-klimatu (accessed on 28 July 2021). (In Polish)

91. Markard, J.; Erlinghagen, S. Technology users and standardization: Game changing strategies in the field of smart meter technology. Technol. Forecast. Soc. Chang. 2017, 118, 226-235. [CrossRef]

92. Willems, B.; Zhou, J. The clean energy package and demand response: Setting correct incentives. Energies $2020,13,5672$. [CrossRef]

93. European Commission. Benchmarking Smart Metering Deployment in the EU-27 with a Focus on Electricity COM(2014) 356 Final; European Commission: Brussels, Belgium, 2014. 
94. European Parliament; Council of the European Union. Directive (EU) 2019/944 on Common Rules for the Internal Market for Electricity and Amending Directive 2012/27/EU; European Parliament: Brussels, Belgium; Council of the European Union: Brussels, Belgium, 2019; pp. 125-199.

95. Energy Regulatory Office. Stanowisko Regulatora w Sprawie Niezbędnych Wymagań Wobec Inteligentnych Systemów Pomiarowo-Rozliczeniowych (The Regulator's Position on the Necessary Requirements for Intelligent Metering and Billing Systems). Available online: https:/ / www.ure.gov.pl/pl/urzad/informacje-ogolne/aktualnosci/4125,Stanowisko-regulatoraw-sprawie-niezbednych-wymagan-wobec-inteligentnych-systemo.html (accessed on 28 July 2021). (In Polish)

96. Innogy. Wymiana Liczników Energii: Wyzwania dla Operatorów-Korzyści dla Klientów (Replacing Energy Meters: Challenges for Operators-Benefits for Customers). Available online: https:/ /www.smart-grids.pl/technologie/3698-wymiana-licznik\% C3\%B3w-energii-wyzwania-dla-operator\%C3\%B3w-korzy\%C5\%9Bci-dla-klient\%C3\%B3w.html (accessed on 28 July 2021). (In Polish)

97. Gramwzielone.pl. Pół Miliona Inteligentnych Liczników u Klientów Taurona (Half a Million Smart Meters at Tauron's Customers). Available online: https:/ / www.gramwzielone.pl/trendy/104589/pol-miliona-inteligentnych-licznikow-u-klientow-taurona (accessed on 28 July 2021). (In Polish)

98. Babś, A. Krajowe wdrożenia systemów inteligentnego opomiarowania (National implementations of smart metering systems). Paliwa i Energ. 2015, 3, 38-41. (In Polish)

99. Drożdż, W.; Wiśniewski, S. Inteligentne liczniki jako narzędzie technologii informacyjnej w elektroenergetyce (Smart meters as a tool of information technology in the power industry). In Rynek Energii Elektrycznej: Rozwój i Eksploatacja; Pijarski, P., Połecki, Z., Eds.; Politechnika Lubelska: Lublin, Poland, 2017. (In Polish)

100. European Commission. Digitalisation-Energy. Available online: https://ec.europa.eu/energy/topics/technology-andinnovation/digitalisation_en (accessed on 13 November 2020).

101. European Parliament; Council of the European Union. Directive 2003/87/EC of the European Parliament and of the Council of 13 October 2003 Establishing a Scheme for Greenhouse Gas Emission Allowance Trading within the Community and Amending Council Directive 96/61/EC; European Parliament: Brussels, Belgium; Council of the European Union: Brussels, Belgium, 2003.

102. Anda, M.; Temmen, J. Smart metering for residential energy efficiency: The use of community based social marketing for behavioural change and smart grid introduction. Renew. Energy 2014, 67, 119-127. [CrossRef]

103. Coutinho, B.; Ferreira, É.; Pena, R.; Nunes, V. Enhancing stakeholders involvement by smart meters deployment campaign. CIRED-Open Access Proc. J. 2017, 2017, 2736-2739. [CrossRef] 